\title{
GC/MS Characterization of Beeswax, Protein, Gum, Resin, and Oil in Romano-Egyptian Paintings
}

\author{
Joy Mazurek * (D), Marie Svoboda and Michael Schilling \\ Getty Conservation Institute, Los Angeles, CA 90049, USA \\ * Correspondence: jmazurek@getty.edu; Tel.: +1-310-440-6850
}

Received: 31 May 2019; Accepted: 13 July 2019; Published: 17 July 2019

\begin{abstract}
This article presents results from a binding media survey of 61 Romano-Egyptian paintings. Most of the paintings (51) are the better-known funerary mummy portraits created using either encaustic or tempera paint medium. Samples from all the paintings (on wooden panels or linen shrouds) were analyzed with gas chromatography/mass spectrometry (GC/MS) to identify waxes, fatty acids, resins, oils, and proteins in one sample. Analytical protocols that utilized three separate derivatization techniques were developed. The first analysis identified free fatty acids, waxes, and fatty acid soaps, the second characterized oils and plant resins, and the third identified proteins. The identification of plant gums required a separate sample. Results showed that fatty acids in beeswax were present as lead soaps and dicarboxylic fatty acids in some samples was consistent with an oxidized oil. The tempera portraits were found to contain predominantly animal glue, revising the belief that egg was the primary binder used for ancient paintings. Degraded egg coatings were found on several portraits, as well as consolidation treatments using paraffin wax and animal glue. The unknown restoration history of the portraits caused uncertainty during interpretation of the findings and made the identification of ancient paint binders problematic. Also, deterioration of the wooden support, residues from mummification, biodegradation, beeswax alteration, metal soap formation, and environmental conditions before and after burial further complicated the analysis. The inherent problems encountered while characterizing ancient organic media in funerary portraits were addressed. The fourteen museums that participated in this study are members of APPEAR (Ancient Panel Paintings: Examination, Analysis, and Research), an international collaborative initiative at the J. Paul Getty Museum whose aim is to expand our understanding of ancient panel paintings through the examination of the materials and techniques used for their manufacture.
\end{abstract}

Keywords: mummy portrait; Egypt; painting; tempera; beeswax; binding media; GC/MS

\section{Introduction}

\subsection{Project Description}

Mummy portraits were excavated after thousands of years of burial in Egyptian tombs and offer unique snapshots of ancient life as seen through the lens of the artisan. The individual in the portraits were members of the elite, with disproportionately large eyes that stare into the distance or straight at the viewer. The techniques used to create them offer a rare glimpse into the progression of portrait painting, as they precede Byzantine icon portraits by hundreds of years. Beeswax was used to create the encaustic portraits, and undoubtedly required skill and mastery of the media. Less is known about the tempera portraits because they have seldom been the subjects of scientific analysis. Identification of ancient paint media is complicated by several factors, including chemical and biological deterioration, the presence of ground layers, and the introduction of animal glue or beeswax in prior conservation treatments. Early published studies often cited by researchers were 
necessarily limited by the capabilities of the available analytical instrumentation. Technology has since vastly improved, thereby creating new avenues for binding media identification by using more sophisticated instrumentation.

The Ancient Panel Paintings: Examination, Analysis, and Research project (APPEAR) is an international collaboration spearheaded by the J. Paul Getty Museum to better understand the materials and techniques used to manufacture mummy portraits. The binding media of 61 paintings (51 mummy portraits and 10 panel paintings) from fourteen museums were studied in this survey. The method for binding media identification combined several protocols for characterizing a range of materials. As presented in the Materials and Methods section, waxes (beeswax and paraffin), proteins (egg, animal glue and casein), oils, and resins (pine resin and mastic) were analyzed in one paint sample using three sample preparation protocols. A second sample was analyzed with a fourth protocol for polysaccharides (plant gums). Encaustic paint samples were studied to determine if the beeswax contained additives that would have improved its working properties. Several of the portraits in this study had been previously reported in the literature as applied "cold" at room temperature or classified as egg tempera. It was anticipated that new insights into the technical art history of these paintings would be attained through the application of a reproducible analytical methodology to a large sample set.

\subsection{History of Mummy Portraits}

Mummy portraits show a combination of ancient Egyptian and Roman influences from the 1st through the 3rd centuries [1]. A number of important studies have provided art historical, technical, and information on their current state of preservation [2-4]. Portrait mummies were first discovered in an Egyptian Necropolis at Saqqara by Pietro Della Valle in 1615 AD. However, it was not until the late 19th century that a Viennese art dealer named Theodor Graf uncovered portraits from the er-Rubayat region in the Fayum and brought them to the public's attention. Very little documentation exists from this period of discovery and exhibition [5]. At the turn of the 20th century, portraits were discovered by Grenfell and Hunt at Tanis and Tebtunis, but their record keeping was poor. Fortunately, excavations conducted by the British Egyptologist Sir William Flinders Petrie were systematically excavated and well-documented over two field seasons at Hawara. Petrie uncovered approximately 146 portraits in mass graves without markers, and described them as relatively rare (only attached to about 1 in 100 mummies). Some portraits were in fair-to-good condition, but others were so badly damaged by water or embalming oil that they were beyond repair [6]. They may have been displayed in homes or at banquets on festival days, which could have exposed them to harsh conditions before burial [7]. Of the more than 1000 portraits in existence today, except for those mentioned, little is known about their provenience because most were illicitly excavated.

\subsection{Treatment and Interventions}

Treatment documentation of the mummy portraits after excavation exists only because of Petrie's meticulous record keeping. During his seasons in the field, he took on many roles, including that of field conservator. The records indicate that he stabilized flaking paint by warming the encaustic portraits and slightly melting the wax. Fragile painted surfaces were also faced with tissue and rice paste [5]. Emergency consolidation treatments were often accomplished with beeswax or paraffin [8,9]. For mummies in poor condition, their portraits were separated and framed [10]. Although Petrie's salvage treatments can still be seen on some portraits today (and may be the reason why so many still exist), he was an advocate for minimal intervention and made every effort to keep the portraits attached to their mummies for context. In contrast, Theodor Graf came into contact with about 350 portraits during his lifetime, but condition and treatment information was not recorded. 


\subsection{Beeswax Paint and Modified Wax}

The act of creating encaustic paintings with molten wax certainly required sophisticated skill, especially when producing the subtle color schemes and swift painterly methods of the ancient artists. Early researchers first postulated that to master encaustic painting, the artisan may have used cold paintable beeswax, which was initially described based on Pliny's recipe for "Punic wax". Also, evidence for the different encaustic painting techniques has routinely been identified in the literature based on visual appearance as well as chemical analysis, such as the formation of metal soaps and the reduction of wax ester components [11-13]. Today, it is generally accepted that the "Punic wax" recipe and terminology is a purification step that whitens the beeswax by extracting the yellow color caused by pollen along with various other impurities [14]. Stacey [15] showed that Pliny's recipe resulted in the formation of fatty acid soaps, thereby changing the chemical signature of beeswax by removing or reducing the free fatty acid content. Thus, a cold paintable wax is best defined as a "modified wax", it has been chemically altered to be fluid at room temperature. Even with modern instrumentation it has been extremely difficult to identify [16]. Although beeswax esters are very stable, hydrolysis can occur over long periods due to biodeterioration, high temperatures, and extreme $\mathrm{pH}$ conditions [17-20].

\subsection{Tempera Paint}

The portraits classified as tempera may have been produced at different workshops than the encaustic portraits [21]. In Egypt, numerous natural materials were available to artists for preparing tempera paint: animal glue, oils, milk, egg, honey and Acacia sp. gum [22]. Proteins may be identified by amino acid analysis; one example is the identification of animal glue in an Egyptian portrait painted on linen [23]. Limitations of amino acid analysis occur when mixtures of proteins are present and results should be interpreted with caution. For example, Mathews [24] reported egg and animal glue mixtures in several Romano-Egyptian paintings, solely based on amino acid analysis. Proteomics has been used for species identification of protein-based binding media and Mazurek [25] identified cow (bovine) skin glue as the species of animal used to prepare the glue binder in tryptic panels.

Plant gum exudates are protein/polysaccharide complexes in which the protein exists as a central core within gum molecules. Plant gums may be identified by the relative ratios of monosaccharides, although limitations exist when mixtures of gums are present [26]. A mixture of locust bean and Acacia sp. plant gums were identified on a mummy portrait on linen [27] by matrix-assisted laser desorption ionization mass spectrometry (MALDI).

\section{Materials and Methods}

Gas chromatography/mass spectrometry (GC/MS) methodologies were combined in order to identify a wide range of organic materials in paint samples. Chemical analysis of the ground layer was not always possible due to limited sample quantities and because of difficulties in separating paint layers. The techniques described in the method section were adapted to identify waxes, free fatty acids, oils, plant resins, fatty acid soaps, and proteins (egg, casein, or animal glue) in a single micro-sample of paint. Three subsequent derivatization procedures were carried out in an Agilent micro vial with a crimp top. First, the sample was tested for waxes and free fatty acids and fatty soaps (Butyl Prep protocol). Next, the sample was tested for oils and resins (Meth Prep protocol). Lastly, the sample was tested for proteins (amino acid protocol). Whenever possible, paint samples were weighed (20-300 $\mu \mathrm{g}$ ) and deposited into $15 \mu \mathrm{L}$ high recovery autosampler vials (Agilent \#5184-3551) fitted with crimp tops (Agilent \#8010-0051). Identification of plant gums by monosaccharide analysis required a separate paint sample; due to limited sample quantities, it was utilized less often.

\subsection{Butyl Prep: Beeswax and Soap Analysis}

Tert-butanol is a tertiary alcohol sterically hindered in transesterification reactions. The Butyl Prep method is a novel derivatization technique adapted from Van Kuijk [28] that utilizes 
3-(trifluoromethyl)phenyl trimethylammonium hydroxide (TMTFTH) or Meth Prep reagent (TCI part \# T0961) in $t$-butanol. It is used to analyze free fatty acids, fatty acid soaps, waxes, and alkyl esters in beeswax and oils.

1) To make the Butyl Prep reagent, add $400 \mu \mathrm{L}$ of Meth Prep reagent into a $2 \mathrm{~mL}$ autosampler vial and evaporate under nitrogen to dryness at $50{ }^{\circ} \mathrm{C}$. Add $50 \mu \mathrm{L}$ of toluene, evaporate to dryness, then add $100 \mu \mathrm{L}$ of $t$-butanol. Mix contents until the salt is in solution, add $600 \mu \mathrm{L}$ of chloroform, then mix until the solution is clear.

2) Add between 20 and $50 \mu \mathrm{L}$ of the Butyl Prep reagent to the paint sample in a high recovery autosampler vial, cover with a crimp top lid, and heat the vial for one hour at $60^{\circ} \mathrm{C}$ in an oven.

3) An Agilent $6890 \mathrm{~N} / 5973$ inert GC/MS system was used for analysis with a Zebron ${ }^{\mathrm{TM}} \mathrm{ZB}-5 \mathrm{HT}$ column $(30 \mathrm{M} \times 0.25 \mathrm{~mm} \times 0.10 \mu \mathrm{m})$ for separation. Helium gas $1.2 \mathrm{~mL} / \mathrm{min}$; splitless injection liner without glass wool at $300^{\circ} \mathrm{C}$; transfer line $320^{\circ} \mathrm{C}$. Oven program: $80^{\circ} \mathrm{C}(2 \mathrm{~min}), 10^{\circ} \mathrm{C} / \mathrm{min}$ to $210^{\circ} \mathrm{C} ; 20^{\circ} \mathrm{C} / \mathrm{min}$ to $360^{\circ} \mathrm{C}(6 \mathrm{~min}) ; 40^{\circ} \mathrm{C} / \mathrm{min}$ to $380^{\circ} \mathrm{C}(2 \mathrm{~min})$. Total run time was $31 \mathrm{~min}$ in SCAN mode $(50-550 \mathrm{~m} / \mathrm{z})$. Fatty acid standards were used for calibration.

\subsection{Meth Prep: Oil Analysis}

Following Butyl Prep analysis, natural plant resins such as pine resin, mastic, and oils were analyzed with Meth Prep. The reagent is used for the transesterification of lipids and the methylation of fatty acids, including dicarboxylic fatty acids formed by oxidation of drying oils. It measures the total amount of fatty acids, including free fatty acids, fatty acid soaps and glycerides. The Meth Prep protocol was described previously $[29,30]$. To get a complete pattern of mono and dicarboxylic fatty acids in beeswax portraits, Meth Prep results for dicarboxylic fatty acids and glycerol were combined with the Butyl Prep results using ESCAPE (Section 2.7).

1) Prepare reagent by diluting (1:2) Meth Prep in toluene.

2) Gently evaporate the Butyl Prep from the micro vials without heat, or allow the solution to evaporate at room temperature.

3) Add between 20 and $50 \mu \mathrm{L}$ of Meth Prep reagent to the vial, cap, and heat at $60^{\circ} \mathrm{C}$ for 1 hour. Inject into GC/MS with the same final volume and instrumental parameters for Butyl Prep.

\subsection{Amino Acid Analysis: Proteins (egg, animal glue, casein)}

The protein identification method utilizes ethyl chloroformate, and has been described previously [31,32]. The percentage of protein is reported as $(\mathrm{mg} / \mathrm{mg})$ amino acids in paint sample. A perfect match to proteins in the reference library is a correlation coefficient (c. coeff.) of 1.0; for some degraded samples, 0.93 is an acceptable match.

1) Evaporate Meth Prep solution in the sample micro vial with nitrogen at $50^{\circ} \mathrm{C}$. Add $100 \mu \mathrm{L}$ of $6 \mathrm{~N}$ $\mathrm{HCL}$, cover with a crimp top lid, and heat at $105^{\circ} \mathrm{C}$ for $24 \mathrm{~h}$ (or $4 \mathrm{~h}$ at $145^{\circ} \mathrm{C}$ ). Then follow the published amino acid protocol for sample preparation.

2) An INNOWAX column $(25 \mathrm{M} \times 0.2 \mathrm{~mm} \times 0.2 \mu \mathrm{m})$ was used for separation. Helium gas $1 \mathrm{~mL} / \mathrm{min}$, splitless injection at $240{ }^{\circ} \mathrm{C}$; transfer line $240{ }^{\circ} \mathrm{C}$. Oven program: $70{ }^{\circ} \mathrm{C}$ for $1 \mathrm{~min} ; 20^{\circ} \mathrm{C} / \mathrm{min}$ to $250{ }^{\circ} \mathrm{C}$; isothermal for $3.5 \mathrm{~min}$. The total run time was $12 \mathrm{~min}$. SIM mode was used. The identification of proteins by GC/MS is accomplished by comparing the amino acids (building blocks of proteins) of each sample to those of standard reference materials using the method of correlation coefficients. Amino acid standards were used for calibration.

\subsection{Monosaccharide Analysis: Plant Gums (Acacia sp. gums, monosaccharides, starch, and honey)}

The procedure is described previously in two publications [26,33]. When the samples were large enough, they were weighed (approximately $100 \mu \mathrm{g}$ ) into $15 \mu \mathrm{L}$ high-recovery crimp-top autosampler vials. Then a published protocol for sample preparation was followed. An INNOWAX column 
$(25 \mathrm{M} \times 0.2 \mathrm{~mm} \times 0.2 \mu \mathrm{m})$ was used for separation. Helium carrier gas was set to a linear velocity of $29 \mathrm{~cm} / \mathrm{s}$. Splitless injection was set to $240^{\circ} \mathrm{C}$. The MS transfer line was set to $260^{\circ} \mathrm{C}$. The GC oven temperature program was $105^{\circ} \mathrm{C}$ for $1 \mathrm{~min} ; 20^{\circ} \mathrm{C} / \mathrm{min}$ to $250{ }^{\circ} \mathrm{C}$; isothermal for $10 \mathrm{~min}$. The total run time is $18.25 \mathrm{~min}$. SCAN mode was used. Monosaccharides standards were used for calibration.

\subsection{Fourier-Transform Infrared Spectroscopy (FTIR)}

A Bruker, Hyperion 3000 FTIR with Omnic 7.1 software was used to identify fatty acid soaps based on library match software. A representative sample particle was placed on a diamond window and analyzed by a transmitted infrared beam with an aperture of approximately $100 \times 100$ microns, using a $15 \mathrm{X}$ objective.

\subsection{Enzyme-linked Immunosorbent Assay (ELISA)}

Mazurek [34] described this method previously, and it was used with a few modifications. The paint samples were treated with $20 \mu \mathrm{L}$ elution buffer and allowed to sit overnight for extraction of proteins. The elution buffer is composed of $10 \mathrm{mM}$ tris- $\mathrm{HCl}, \mathrm{pH} 7.4,0.5 \mathrm{M}$ EDTA, 6M Urea, $1 \%$ Sodium dodecyl sulfate (SDS) in deionized water. After extraction in $2 \mathrm{~mL}$ centrifuge tubes, $80 \mu \mathrm{L}$ of $100 \mathrm{mM}$ sodium bicarbonate. Egg ovalbumin antibody (\#AB1225), with rabbit IgG (\#AP132A). Sea block was utilized and PNPP (p-nitrophenyl phosphate detection read by a microplate spectrophotometer, Finstruments model \#341.

\subsection{ESCAPE Data Evaluation}

GC/MS data from Meth Prep and Butyl Prep analysis were evaluated using ESCAPE (Expert System for Characterization using AMDIS Plus Excel) which was developed for interpreting Pyrolysis-GCMS data for decorative lacquers from Asia and Europe [35]. AMDIS (Automated Mass Spectral Deconvolution \& Identification System) is part of the NIST MS Search version 2.3 software. AMDIS was used to automatically identify and measure peak areas for beeswax and oil components, including monocarboxylic, dicarboxylic, saturated and unsaturated fatty acids, alcohols, hydrocarbons, and wax esters. The AMDIS report was saved as a text file and exported to a customized EXCEL report template developed for data interpretation in this project. The EXCEL database contains all paint samples and the deconvoluted peak areas. The Butyl Prep and the Meth Prep data were combined to get the complete fatty acid profile.

\subsection{Reference Materials}

1) An ancient beeswax writing tablet (6-20403), Roman Empire (27 BC-395 AD). $14 \mathrm{~cm} \times 18 \mathrm{~cm} \times$ $0.5 \mathrm{~cm}$. Arthur S. Hunt and Bernard P. Grenfell. Roman tomb, Tebtunis, Faiyum region. Phoebe Hearst Museum

2) 19th C Beeswax, black color, Boston Museum of Fine Arts

3) Fresh Beeswax from GCI reference collection

4) Mummy portraits and panel paintings are described in Table 1 
Table 1. Summary of mummy portraits and panel paintings tested. Panel shape is described as follows: $\Omega=$ Round Top, $\Delta=$ Angled Edges, $\Pi=$ uncut. Clib = Cedrus libani, cedar of Lebanon, Fsyc = Ficus sycomorus (sycomore fig), Tileu = Tilia europaea (lime/linden). The most likely provenience/provenance is shown in parenthesis and italics under Source.

\begin{tabular}{|c|c|c|c|c|}
\hline Accession & Source & $\begin{array}{l}\text { Date } \\
\text { A.D. }\end{array}$ & $\begin{array}{l}\text { Wood } \\
\text { (MM) }\end{array}$ & Technique \\
\hline \multicolumn{5}{|c|}{ J Paul Getty Museum } \\
\hline 71.AP.72 & (Hawara) & $100-125$ & $\Omega$ Tileu (2) & Beeswax, heavy, impasto \\
\hline 73.AP.91 & (Hawara) & 75-100 & $\Omega$ Tileu (2) & Beeswax, lean, cracking, glue ${ }^{1}$ \\
\hline 73.AP.94 & - & $140-160$ & $\Omega$ Tileu (2) & Beeswax, flat, lean, restored \\
\hline 74.AP.11 & (er-Rubayat) & $150-170$ & $\Delta$ Tileu (2) & Beeswax, heavy, (egg coating) \\
\hline 74.AP.20 & - & $180-200$ & П Fsyc (3) & Glue tempera, flat, (egg coating) \\
\hline 74.AP.21 & (er-Rubayat) & $100-200$ & П Fsyc (16) & Glue tempera, flat, (egg coating) \\
\hline 74.AP.22 & (er-Rubayat) & 100-200 & П Fsyc (16) & Glue tempera, flat, (egg coating) \\
\hline 75.AP.87 & - & $150-250$ & Linen & Glue tempera, flat \\
\hline 78.AP.262 & - & $150-200$ & П Tileu (1.4) & Beeswax, impasto, bubbles in wax \\
\hline 79.AP.129 & (er-Rubayat)/Graf & $175-200$ & П Clib (11) & Glue tempera, flat, lean \\
\hline 79.AP.141 & - & $220-235$ & П Clib (11) & Beeswax, lean, impasto, cracking glue ground \\
\hline 79.AP.142 & (er-Rubayat) & $220-250$ & $\Delta$ Clib (11) & Glue \& gum tempera, flat, heavy \\
\hline 79.AP.219 & - & $220-250$ & Linen & Glue tempera \\
\hline 81.AP.29 & (er-Rubayat)/Graf & 170-200 & $\Delta$ Fsyc (11) & Glue tempera \\
\hline 81.AP.42 & - & $100-110$ & $\Omega$ Tileu (1.7) & Beeswax, heavy, impasto \\
\hline 91.AP.6 & (el-Hibbeh) & $50-100$ & $\Omega$ Tileu & Glue tempera, flat, (egg coating) \\
\hline \multicolumn{5}{|c|}{ Ny Carlsberg Glyptotek } \\
\hline AEIN680 & (er-Rubayat)Graf & $100-125$ & $\Omega$ Tileu (2) & Beeswax, lean, impasto, glue ${ }^{1}$ \\
\hline AEIN681 & (er-Rubayat)Graf & $125-150$ & $\Omega$ Tileu (1) & Beeswax, lean, impasto, glue ${ }^{1}$, (egg coating) \\
\hline AEIN682 & (er-Rubayat)Graf & $140-160$ & $\Delta$ Tileu (2) & Beeswax, impasto, white bloom, glue 1 \\
\hline AEIN683 & (er-Rubayat)Graf & $125-150$ & $\Omega$ Tileu (1.5) & Beeswax, impasto \\
\hline AEIN684 & (er-Rubayat)Graf & $140-200$ & $\Delta$ Tileu (1) & Beeswax, glue ${ }^{1}$, (egg coating) \\
\hline AEIN685 & - & - & $\Pi$ panel & Gum tempera, flat \\
\hline AEIN686 & - & - & $\Pi(F s y c)(12)$ & Glue tempera, flat \\
\hline AEIN1425 & Hawara, Petrie & $25-75$ & Linen & Beeswax, lean, heat ${ }^{2}$ \\
\hline AEIN1426 & Hawara, Petrie & $100-125$ & $\Omega$ Tileu (1.5) & Beeswax, impasto, (paraffin) \\
\hline AEIN1473 & Hawara, Petrie & $100-150$ & $\Omega$ Tileu (2.5) & Beeswax, impasto heat ${ }^{2}$, (paraffin) \\
\hline \multicolumn{5}{|c|}{ National Museum Demark } \\
\hline AS 3891 & er-Rubayat & $150-200$ & $\Delta$ Tileu (1.5) & Beeswax, impasto \\
\hline AS 3892 & (er-Rubayat) & $150-200$ & $\Omega$ Tileu (1.5) & Beeswax, impasto \\
\hline AS 8940 & er-Rubayat & $100-125$ & $\Delta$ Fsyc $(11)$ & Glue tempera, flat \\
\hline \multicolumn{5}{|c|}{ Santa Barbara Museum of Art } \\
\hline VL.2015.5 & - & $3-4$ th C & $\Delta$ panel (6) & Glue tempera, flat \\
\hline \multicolumn{5}{|c|}{ Museum of Fine Art Houston } \\
\hline CA5879 & (Sheikh) & $150-200$ & Linen & Tempera $^{7}$, flat \\
\hline 1984-45DJ & - & $200-250$ & $\Pi$ panel (10) & Beeswax, impasto, (shellac) \\
\hline 1970 001DJ & - & Modern & $\Delta$ pinus (2) & Linseed oil, impasto \\
\hline CA5878 & - & Modern & $\Pi$ fagus (1) & Linseed oil, flat \\
\hline CA7124 & (er-Rubayat)Graf & 150-200 & $\Delta$ Fsyc (10) & Beeswax, flat \\
\hline CA7013 & - & $150-200$ & $\Delta$ Tileu (1.4) & Beeswax, impasto \\
\hline \multicolumn{5}{|c|}{ Museum of Fine Art Houston } \\
\hline TR:184-2013 & - & $1-200$ & $\Omega$ Tileu (2.4) & Beeswax, impasto \\
\hline 2009.16 & - & $1-100$ & $\Omega$ Tileu (2.5) & Beeswax, impasto \\
\hline \multicolumn{5}{|c|}{ Los Angeles County Museum } \\
\hline M.71.73.62 & Graf & $3-4$ th C & $\Delta$ panel (6) & Glue tempera, flat \\
\hline \multicolumn{5}{|c|}{ Walters Art Museum } \\
\hline 32.4 & Antinoöpolis & $130-300$ & Beech (6) $)^{3,4}$ & Beeswax, (paraffin) \\
\hline 32.6 & (er-Rubayat) & $117-138$ & $\Delta$ Tileu (2) ${ }^{4}$ & Beeswax, saliva cleaning \\
\hline \multicolumn{5}{|l|}{ Ashmolean } \\
\hline AN188.342 & - & - & $\Omega$ Tileu (1.5) & Beeswax and glue tempera \\
\hline \multicolumn{5}{|c|}{ Cantor Arts Center } \\
\hline JLS.22225 & - & 180-235 & $\Delta$ panel (2.4) & Beeswax \\
\hline JLS.22226 & - & - & $\Delta$ panel & Glue tempera (oil, mastic, paraffin) \\
\hline \multicolumn{5}{|c|}{ Yale University Art Gallery } \\
\hline 1935.551 & Europos, Hopkins & 256 & Round & Glue tempera (beeswax, paraffin) \\
\hline
\end{tabular}


Table 1. Cont.

\begin{tabular}{|c|c|c|c|c|}
\hline Accession & Source & $\begin{array}{l}\text { Date } \\
\text { A.D. }\end{array}$ & $\begin{array}{l}\text { Wood } \\
\text { (MM) }\end{array}$ & Technique \\
\hline \multicolumn{5}{|c|}{ Phoebe Hearst Museum } \\
\hline $5-2327$ & Kerke, Graf & 300 & Fsyc (3) ${ }^{5}$ & Glue tempera, flat \\
\hline 6-21377 & Tebtunis, Hunt & 96-192 & $\Delta$ Fsyc (12) & Beeswax, impasto, heavy \\
\hline 6-21384 & Tebtunis, Hunt & $1-395$ & П Ziziphus & Glue tempera, flat, lean \\
\hline $6-21385$ & Tebtunis, Hunt & $1-395$ & П Ziziphus & Glue tempera, flat, lean \\
\hline $6-21386$ & Tebtunis, Hunt & $1-395$ & П Ziziphus & Glue tempera, flat, lean \\
\hline $6-21387$ & Tebtunis, Hunt & $1-395$ & П Cedar & Protein tempera ${ }^{7}$, flat, lean \\
\hline \multicolumn{5}{|c|}{ Petrie Museum } \\
\hline UC14768 & Kafr Ammar, Petrie & $160-180$ & Fir $^{6}$ & Glue tempera \\
\hline UC19607 & Hawara, Petrie & $100-120$ & $\Delta$ Tileu (4) & Beeswax, (paraffin) \\
\hline UC19608 & Hawara, Petrie & $70-100$ & $\Delta$ Tileu (2) & Beeswax \\
\hline UC19610 & Hawara, Petrie & $140-160$ & $\Delta$ Tileu (2) & Beeswax \\
\hline UC19612 & Hawara, Petrie & $160-170$ & $\Delta$ Tileu (2) & Beeswax \\
\hline UC30081 & Hawara, Petrie & $100-120$ & $\Delta$ Tileu (2) & Beeswax, (paraffin) \\
\hline UC33971 & Hawara, Petrie & $100-130$ & $\Delta$ Tileu (4) & Beeswax, (paraffin) \\
\hline \multicolumn{5}{|c|}{ Cleveland Museum of Art } \\
\hline 1971.135 & - & 138-192 & linen & Beeswax, (paraffin) \\
\hline 1971.136 & - & 138-192 & linen & Beeswax, (paraffin) \\
\hline
\end{tabular}

\footnotetext{
${ }^{1}$ Consolidated with animal glue. ${ }^{2}$ Consolidated with heat. ${ }^{3}$ Stepped shape. ${ }^{4}$ Wood ID by USDA forest service.
}

${ }^{5}$ Panel cut in ogee shape. ${ }^{6}$ Wood ID Royal Botanic Gardens. ${ }^{7}$ No binder identified

\section{Results}

\subsection{Summary}

Table 1 provides a summary of the results for 61 objects-mummy portraits on wooden panels and linen shrouds (51), portrait panels and hinged doors (9), and a Roman shield (1)—including the accession number, provenience, stylistic date, panel shape (rounded, angled or uncut), wood species and panel thickness. The provenience and provenance (collection history) of a portrait is reported when known, and when conjectured it is given in italics and parenthesis. The description of the paint application was defined as follows: heavy indicates a thickly applied paint layer, whereas lean indicates a matte or thin paint layer. Paint applied as impasto shows evidence of tool marks that sculpted the medium, whereas flat indicates paint with no obvious tool marks (which is often seen in tempera portraits). Cartwright [36,37] identified the majority of the species of wood used to manufacture the panels, and the results are included in Table 1. Panel thicknesses for beeswax portraits are typically very thin, $2 \mathrm{~mm}$ on average, and are identified as Tilia europaea, also known as lime or linden wood. Tempera portraits are most often on thicker panels, $11 \mathrm{~mm}$ on average, and are most often composed of Ficus sycomorus, a fig tree belonging to the Moraceae family or Cedrus libani, a cedar of Lebanon.

Sutherland's [38] binding media terminology was applied in order to accurately describe the tempera technique. Table 1 shows the tempera identified using the protocols outlined in the Materials and Methods. If the proteinaceous binding media could not be positively identified, it was described as protein tempera. Further, if the binder was completely unknown, it was described as tempera. Some portraits have documentation describing past treatments, such as consolidation with heat or animal glue, and were noted as such. Other materials identified by GC/MS or ELISA, such as egg coatings and paraffin wax, are indicated with parentheses.

\subsection{Beeswax Portraits}

Figure 1 shows a typical result for paraffin wax in a mummy portrait from the Petrie Museum (UC 33971). Paraffin wax was identified by a characteristic pattern of odd- and even-numbered hydrocarbons that resembled a skewed bell-shaped curve. Eight portraits contained high amounts of paraffin wax used for consolidation; of these, three were from the Petrie Museum. This confirmed 
Petrie's reported use of paraffin as an emergency consolidation treatment. Figure 2 shows the Butyl Prep GC/MS total ion chromatograms (TIC) for beeswax samples without lead-based pigments to illustrate aging behavior. The top chromatogram is beeswax from the 19th century and the bottom is from an Egyptian wax tablet from the 1st to 3rd centuries from the Phoebe Hearst Museum (6-20403). Beeswax is a relatively stable material, as shown by the consistent amounts of palmitic acid $\left(\mathrm{C}_{16}\right)$, tetracosanoic acid $\left(\mathrm{C}_{24}\right)$, and beeswax esters $\left(\mathrm{C}_{40}-\mathrm{C}_{48}\right)$. Other than a reduction in hydrocarbons and fatty acids in the ancient sample, the chemical profile of the ancient wax tablet was still remarkably similar to the modern beeswax sample
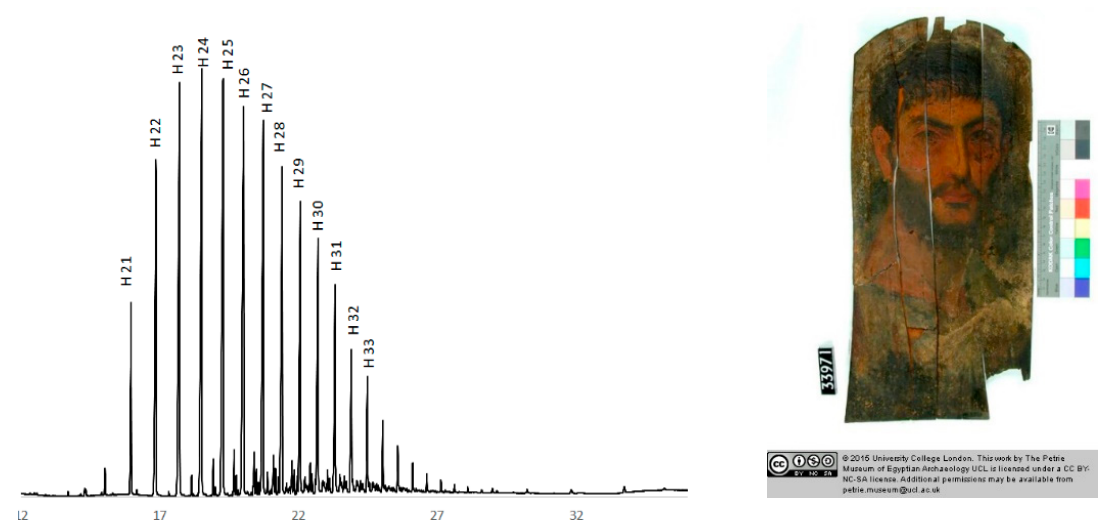

Figure 1. Butyl Prep partial chromatogram (TIC) showing paraffin wax in a mummy portrait from the Petrie Museum (UC 33971).
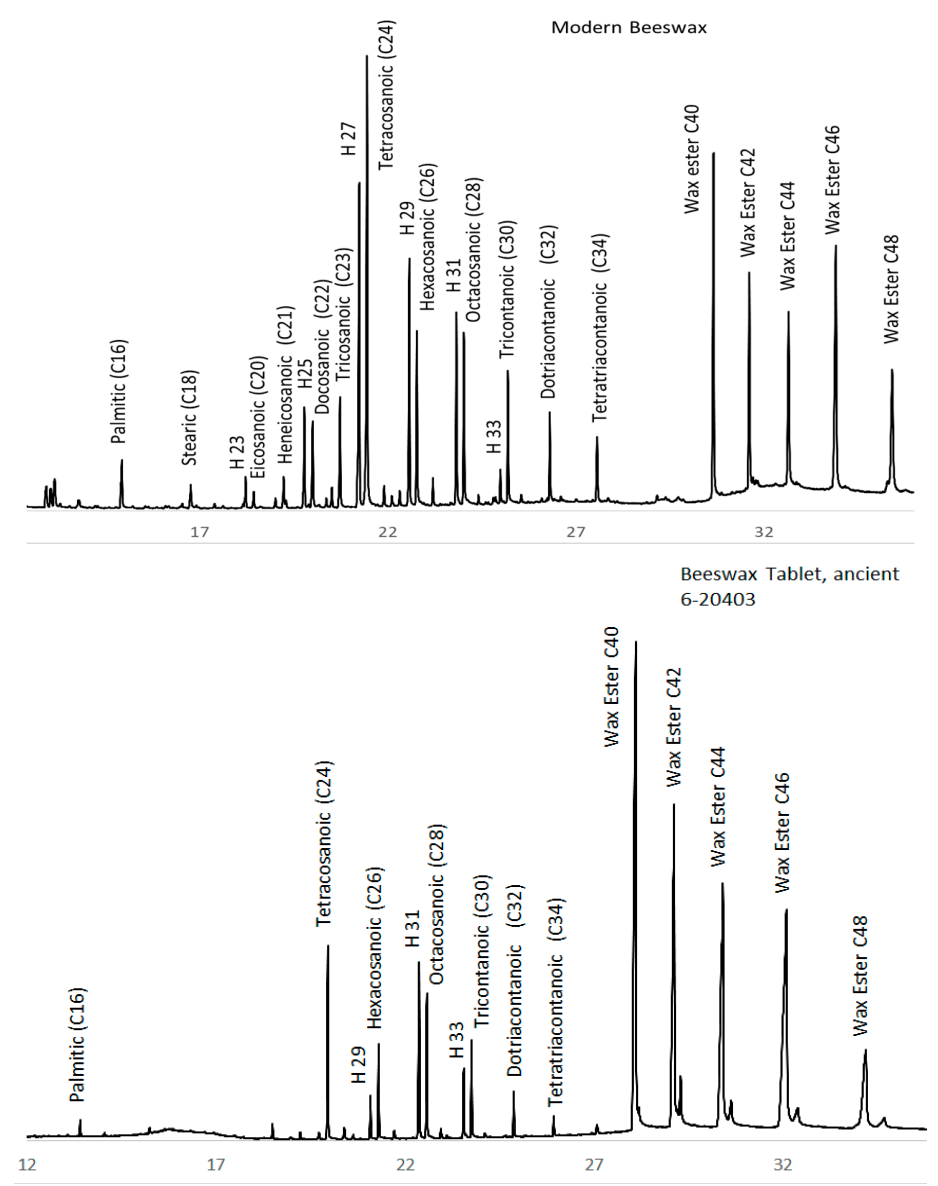

Figure 2. Butyl prep analysis. Partial TIC for a 19th century beeswax (top). Ancient writing tablet from the Phoebe Hearst Museum (6-20403) (bottom). H = hydrocarbons and number of carbons. 
Table 2 details the relative percent peak areas of palmitic acid, wax esters, dicarboxylic fatty acids, and monocarboxylic fatty acids in the beeswax portraits. The peak areas were quantified with ESCAPE and percent values were obtained by dividing each category (wax esters, saturated and unsaturated monocarboxylic fatty acids, and dicarboxylic fatty acids) by the total sum. Dicarboxylic fatty acids formed by the oxidation of lipids and oils were measured from the Meth Prep analysis. Hydrocarbons were not included in the beeswax analysis because they were common to both beeswax and paraffin wax. Pine resin was detected on several portraits, and likely originated from resin in the mummy wrappings.

Table 2. Peak area percentages for palmitic acid (P), wax esters (WE), dicarboxylic fatty acids (Di), and monocarboxylic fatty acids (FA). Sample locations designated as: BG = background, Bot $=$ bottom, $\mathrm{C}=$ center $\mathrm{PR}=$ proper right, $\mathrm{PL}=$ proper left. Monos $=$ monosaccharides no match. Protein $=$ no match. Skin $=$ match epidermal skin. Glue $=$ amino acids match animal collagen. Brassica $=\mathrm{C} 22: 1$ or erucic acid (seed oil from the Mustard family). Pine = abietic acids from pine resin.

\begin{tabular}{|c|c|c|c|c|c|c|}
\hline ID & Location & $\mathbf{P}$ & WE & Di & FA & Other \\
\hline \multicolumn{7}{|c|}{ 71.AP.72 Beeswax } \\
\hline white & tunic bot PR & 46 & 16 & 1 & 36 & protein, monos \\
\hline white & tunic bot PL & 52 & 11 & 5 & 32 & protein, monos, pine \\
\hline \multicolumn{7}{|c|}{ 73.AP.91 Beeswax } \\
\hline grey & BG, C PL & 76 & 2 & 5 & 18 & \\
\hline purple & shoulder PL & 69 & 5 & 0.5 & 26 & pine \\
\hline \multicolumn{7}{|c|}{ 73.AP.94 Beeswax } \\
\hline white & BG, C PR & 9 & 19 & - & 72 & pine \\
\hline \multicolumn{7}{|c|}{ 74.AP.11 Beeswax with egg coating } \\
\hline flesh & shoulder, PR & 50 & 16 & 3 & 32 & protein, pine \\
\hline grey & BG, top PR & 37 & 13 & 11 & 39 & protein, pine, brassica \\
\hline flesh & cheek, PL & 51 & 0.5 & 15 & 34 & pine, brassica \\
\hline \multicolumn{7}{|c|}{ 75.AP.262 Beeswax } \\
\hline white & BG, top, PR & 17 & 28 & 3 & 52 & \\
\hline white & tunic, $\mathrm{PL}$ & 29 & 22 & 10 & 39 & pine \\
\hline \multicolumn{7}{|c|}{ 79.AP.141 Beeswax on plant gum black ground } \\
\hline white & tunic, PR & 24 & 7 & 0.4 & 68 & pine \\
\hline green & bot, C & 11 & 30 & 2 & 56 & protein \\
\hline \multicolumn{7}{|c|}{ 81.AP.42 Beeswax } \\
\hline flesh & shoulder, PL & 31 & 8 & 0.2 & 61 & pine \\
\hline red & edge, bot PR & 19 & 41 & 3 & 36 & pine \\
\hline \multicolumn{7}{|c|}{ AEIN 680 Beeswax } \\
\hline yellow & clavi, bot L & 30 & 15 & 1 & 53 & pine \\
\hline grey & $\mathrm{BG}, \mathrm{C}$ top & 19 & 25 & 1 & 55 & \\
\hline black & hair, $C$ top & 7 & 30 & 0.5 & 63 & glue \\
\hline \multicolumn{7}{|c|}{ AEIN 681 Beeswax } \\
\hline black & hair, PL & 2 & 41 & 1 & 56 & pine \\
\hline flesh & neck, PR & 9 & 35 & 2 & 55 & glue, pine \\
\hline grey & $\mathrm{BG}, \mathrm{C}$ top & 12 & 37 & 4 & 48 & glue, pine \\
\hline \multicolumn{7}{|c|}{ AEIN 682 Beeswax } \\
\hline flesh & chest, PR & 41 & 19 & 4 & 36 & glue \\
\hline black & hair, TL & 16 & 37 & 3 & 45 & protein \\
\hline \multicolumn{7}{|c|}{ AEIN 683 Beeswax } \\
\hline yellow & jewelry, C & 2 & 80 & 1 & 16 & skin \\
\hline black & hair, edge PR & 13 & 29 & 2 & 57 & \\
\hline flesh & forehead, C & 13 & 31 & 6 & 50 & \\
\hline \multicolumn{7}{|c|}{ AEIN 684 Beeswax with egg coating } \\
\hline black & eyelid, PL & 8 & 54 & 3 & 35 & protein \\
\hline beige & edge, top PR & 31 & 29 & 3 & 37 & protein, pine \\
\hline
\end{tabular}


Table 2. Cont.

\begin{tabular}{|c|c|c|c|c|c|c|}
\hline ID & Location & $\mathbf{P}$ & WE & Di & FA & Other \\
\hline \multicolumn{7}{|c|}{ AEIN 1425 Beeswax } \\
\hline flesh & neck, textile & 26 & 27 & 2 & 45 & protein, pine \\
\hline flesh & chin, PL & 55 & 9 & 4 & 33 & pine \\
\hline grey & BG, bot PL & 33 & 24 & 6 & 37 & pine \\
\hline \multicolumn{7}{|c|}{ AEIN 1426 Beeswax } \\
\hline grey & BG, top PL & 33 & 24 & 6 & 37 & pine \\
\hline black & shoulder, PR & 4 & 33 & 0.4 & 63 & \\
\hline white & tunic, top PL & 13 & 28 & 3 & 57 & protein \\
\hline \multicolumn{7}{|c|}{ AEIN 1473 Beeswax } \\
\hline grey & BG, C top & 31 & 20 & 2 & 47 & glue \\
\hline black & hair, on crack & 19 & 41 & 2 & 39 & glue \\
\hline white & edge, bot PR & 33 & 20 & 1 & 46 & glue \\
\hline \multicolumn{7}{|c|}{ AS 3891 Beeswax } \\
\hline green & dress & 7 & 47 & 1 & 45 & protein \\
\hline grey & grey & 12 & 41 & 1 & 45 & glue \\
\hline \multicolumn{7}{|c|}{ AS 3892 Beeswax } \\
\hline black & hair & 10 & 34 & 4 & 52 & protein, pine \\
\hline white & dress & 3 & 41 & 1 & 55 & skin, pine \\
\hline \multicolumn{7}{|c|}{ TR:184-2013 Beeswax } \\
\hline flesh & chest, PR & 22 & 19 & 2 & 57 & glue \\
\hline \multicolumn{7}{|c|}{ 2009.16 Beeswax } \\
\hline brown & eye, PL & 3 & 31 & 1 & 64 & monos \\
\hline black & hair, $C$ & 3 & 26 & 2 & 70 & glue, pine \\
\hline \multicolumn{7}{|c|}{ CA 7124 Beeswax } \\
\hline grey & edge, top PR & 23 & 19 & 4 & 55 & glue, monos \\
\hline \multicolumn{7}{|c|}{ CA 7013 Beeswax } \\
\hline flesh & chest & 40 & 11 & 5 & 44 & monos, pine \\
\hline \multicolumn{7}{|c|}{ 32.4 Beeswax } \\
\hline black & edge, top PL & 34 & 17 & 6 & 43 & glue, pine, brassica \\
\hline white & tunic, $\mathrm{C}$ & 22 & 23 & 19 & 37 & pine \\
\hline \multicolumn{7}{|c|}{ 32.6 Beeswax } \\
\hline black & hair & 4 & 56 & 0 & 40 & glue \\
\hline white & BG & 13 & 30 & 0.1 & 57 & pine \\
\hline \multicolumn{7}{|c|}{ JLS22225 Beeswax } \\
\hline grey & BG & 19 & 20 & 12 & 49 & pine \\
\hline orange & tunic & 23 & 18 & 3 & 56 & pine \\
\hline \multicolumn{7}{|c|}{ 6-21377 Beeswax } \\
\hline white & tunic & 20 & 43 & 2 & 35 & \\
\hline grey & $\mathrm{BG}$ & 13 & 52 & 1 & 34 & protein \\
\hline flesh & & 26 & 30 & 5 & 40 & \\
\hline \multicolumn{7}{|c|}{ UC 19607 Beeswax } \\
\hline \multicolumn{7}{|c|}{ UC 19608 Beeswax } \\
\hline brown & BG, top C & 43 & 9 & 18 & 31 & glue, pine, brassica \\
\hline \multicolumn{7}{|c|}{ UC 19610 Beeswax } \\
\hline grey & BG, C PL & 64 & 4 & 7 & 25 & pine \\
\hline \multicolumn{7}{|c|}{ UC 19612 Beeswax } \\
\hline \multicolumn{7}{|c|}{ UC 30081 Beeswax } \\
\hline white & $\mathrm{BG}, \mathrm{PR}$ & 19 & 5 & - & 77 & \\
\hline \multicolumn{7}{|c|}{ UC 33971 Beeswax } \\
\hline brown & BG, edge, PR & 37 & 21 & - & 42 & glue \\
\hline References & & & & & & \\
\hline $6-20403$ & tablet & 0.4 & 80 & 0.2 & 20 & \\
\hline GCI & beeswax & 3 & 47 & 0.5 & 48 & \\
\hline
\end{tabular}




\subsection{FTIR: Beeswax and Metal Soaps}

FTIR analysis was used on select samples to detect the presence of metal soaps. Figure 3 compares spectra from two portraits: a copper-based green paint (JPGM 79.AP.141) and a lead white paint (JPGM 71.AP.72). The spectrum from the white paint best matched lead soap and beeswax. The spectrum from green paint best matched copper soap and beeswax. GC/MS analysis identified $46 \%$ palmitic acid and $16 \%$ wax esters in the white paint and $11 \%$ palmitic acid and $30 \%$ wax esters in the green paint. Figure 4 is a detailed image of the white beeswax showing clean bristle marks and small particles present at the end of long strokes of paint, which is consistent with the application of melted wax by brush. GC/MS analysis of the white paint showed high amounts of palmitic acid and reduced wax esters, and FTIR confirmed the presence of lead soaps, all of which indicate that hydrolysis of wax esters occurred.

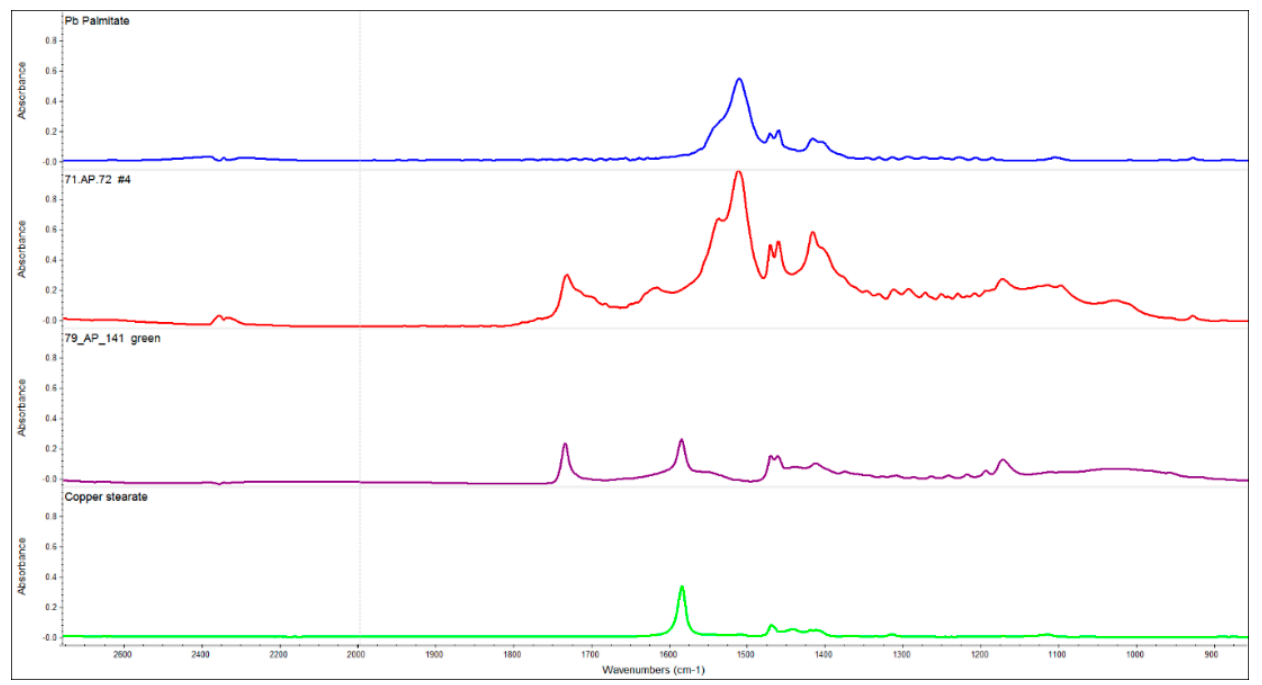

Figure 3. FTIR analysis results. The second spectrum is a white lead-based paint (JPGM 71.AP.72) and the third spectrum is a green copper-based paint (JPGM 79.AP.141). The top spectrum is lead palmitate and the bottom is copper stearate.

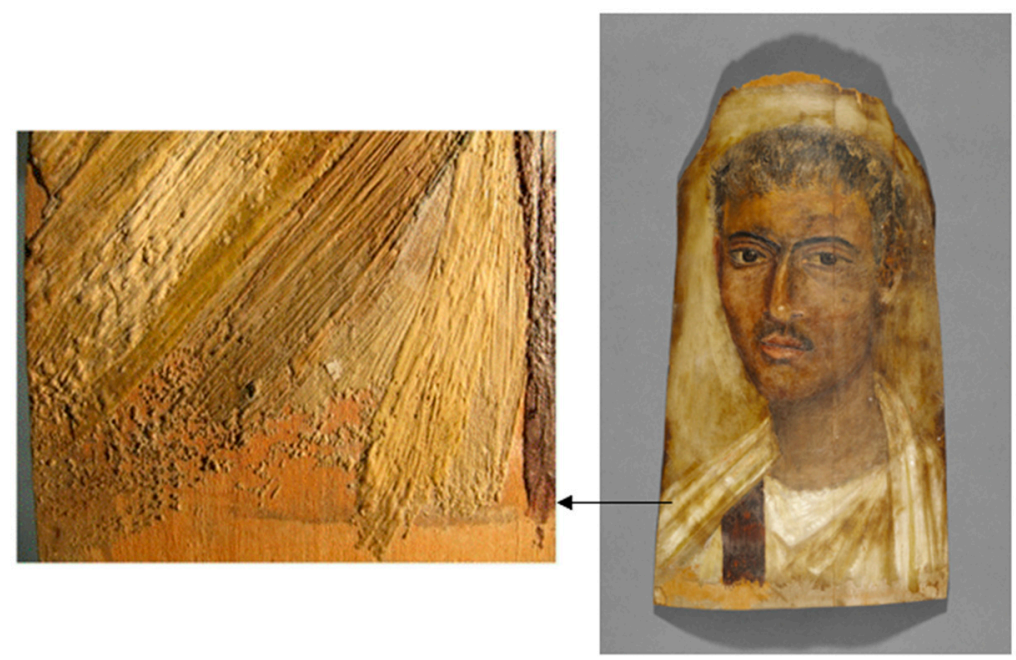

Figure 4. Mummy Portrait of a Man, A.D. 100-125 (JPGM 71.AP.72). The photo on the left shows the detail of the sample location. Image by Marie Svoboda. 


\subsection{Meth Prep: Oil Analysis}

Meth Prep reacts with oxidized oils by transesterification of triglycerides, resulting in a series of methylated dicarboxylic acids that were formed by autoxidation of the unsaturated fatty acids, and methyl ethers originating from glycerol. More than half of the beeswax portraits showed evidence of oxidized oil due to the presence of dicarboxylic acids, however, glycerol was rarely detected. Figure 5 shows results for a mummy portrait from the Petrie Museum of Egyptian Archaeology (UC19608) overlaid with the ancient wax tablet from the Phoebe Hearst Museum (6-20403). The portrait contains $43 \%$ palmitic acid, $9 \%$ wax esters and $18 \%$ dicarboxylic fatty acids, whereas the tablet contains $0.4 \%$ palmitic acid, $80 \%$ wax esters and $0.2 \%$ dicarboxylic fatty acids. The portrait sample also contained trace amounts of erucic acid $\left(\mathrm{C}_{22: 1}\right)$, which is a marker for Brassicaceae (mustard family) oil, as well as oleic acid $\left(\mathrm{C}_{18: 1}\right)$.
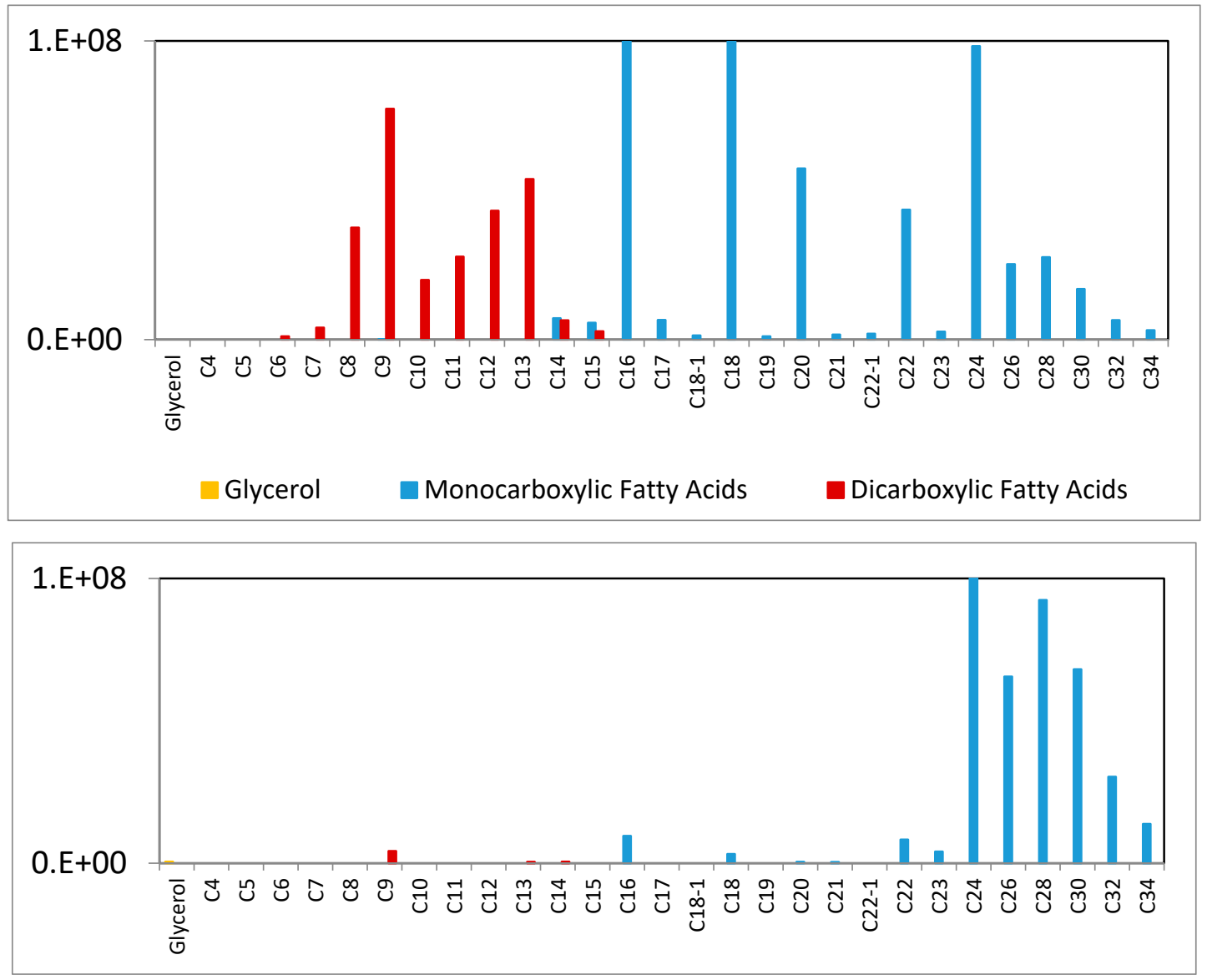

Figure 5. Peak area results for dicarboxylic fatty acids from Meth Prep (red), monocarboxylic fatty acids from Butyl Prep (blue), and glycerol from Meth Prep (yellow). The top graph shows a beeswax portrait from the Petrie Museum of Egyptian Archaeology (UC 19608) and the bottom graph shows beeswax from an ancient wax tablet, Phoebe Hearst Museum (6-20403).

\subsection{Location of Oxidized Oil in Beeswax Paint Samples}

The stratigraphy of three large samples were studied in order to pinpoint the location of oil in the beeswax paint. Two samples were red paint (JPGM 91.AP.6 and JPGM 81.AP.42) and one white paint sample from the tunic (AEIN 1426). Table 3 shows the relative amounts of dicarboxylic fatty acids in the top and bottom areas within the paint fragments. Dicarboxylic fatty acids were not localized on the surface of the paint, which means that oil was not a surface application in these cases. 
Table 3. Analysis of oil based on stratigraphy. Red lead paint from mummy (JPGM 91.AP.6 and JPGM 81.AP.42) and white paint from tunic, Ny Carlsberg Glyptotek (AEIN 1426).

\begin{tabular}{cccccc}
\hline ID & Location & $\mathbf{P}$ & WE & Di & FA \\
\hline $\begin{array}{c}\text { 91.AP.6 Beeswax } \\
\text { red }\end{array}$ & top & 3 & 25 & 15 & 57 \\
& middle & 15 & 25 & 13 & 47 \\
b1.AP.42 Beeswax & bottom & 19 & 18 & 21 & 41 \\
red & top & 28 & 6 & 5 & 61 \\
AEIN 1426 Beeswax & bottom & 29 & 5 & 6 & 60 \\
white & top & 7 & 32 & 7 & 53 \\
& bottom & 12 & 33 & 3 & 52 \\
\hline
\end{tabular}

\subsection{Amino Acid Analysis}

Table 4 shows stable amino acid data for selected reference proteins for comparison. Schilling [32] reported that the so-called "stable amino acids" were less sensitive to the effects of aging and pigments. There are many sources of amino acids, and not all could be included here. Relevant proteinaceous materials illustrate the fact that mixtures of proteins can complicate interpretation.

Table 4. The stable amino acids (mole \%) for selected reference proteins. Ala = alanine, val = valine, ile $=$ isoleucine leu = leucine gly = glycine, pro = proline, $\mathrm{ohp}=$ hydroxyproline .

\begin{tabular}{cccccccc}
\hline Sample & ALA & VAL & ILE & LEU & GLY & PRO & OHP \\
\hline Egg & 23 & 16 & 14 & 21 & 19 & 7 & 0 \\
Human, skin & 16 & 11 & 10 & 22 & 34 & 6 & 0 \\
Isinglass, AG & 18 & 3 & 2 & 4 & 47 & 15 & 10 \\
Collagen, AG & 16 & 3 & 2 & 4 & 47 & 17 & 12 \\
Mummy Skin & 20 & 7 & 5 & 10 & 34 & 16 & 7 \\
Saliva & 11 & 8 & 5 & 12 & 27 & 35 & 0.7 \\
Casein & 11 & 17 & 13 & 22 & 9 & 29 & 0 \\
Egyptian Fungus & 22 & 11 & 7 & 13 & 38 & 8 & 2 \\
\hline
\end{tabular}

Table 5 presents a summary of all the objects tested for amino acids. Amino acids were found in a majority of beeswax portraits, and some were consistent with animal glue (correlation coefficient between 0.93 and 0.99 ). The amino acid composition occasionally matched skin epidermis, or egg (from coatings); some did not match a known reference material. Not all samples were tested by ELISA, as sample amounts were often limited. Relative amounts of protein content were included when sample weights were measured.

Samples from the tempera portraits contained between $1 \%$ and $3 \%$ protein that most closely matched animal glue (collagen). Animal glue was identified in a paint sample from a Petrie Museum portrait (UC 14768) that Ramer [39] identified as egg tempera on the basis of fatty acid profiles. This was one of the earliest studies of these paintings, and has been often cited in literature, even though Mills and White [40] reported that fatty acid profiles are not ideal for identifying egg tempera.

Three portrait panels and/or hinged doors from the Phoebe Hearst Museum (6-21384, -85, -86) were identified as glue tempera. Two tempera portrait panels (6-21387 and CA 5879) could not be characterized due to limited sample amounts. The Roman shield from Yale previously restored with PVA and beeswax contained glue tempera. Glue tempera was also identified in a portrait panel from Ny Carlsberg Glyptotek (AEIN 685). 
Table 5. Summary of stable amino acids ( $\mathrm{mol} \%$ ). bot = bottom, $\mathrm{C}=$ center, $\mathrm{BG}=$ Background, $\mathrm{PR}=$ proper right, $\mathrm{PL}=$ proper left. Stable amino acid values given in mole $\%$. Ala = alanine, $\mathrm{val}=$ valine ile $=$ isoleucine, $\mathrm{leu}=$ leucine, $\mathrm{gly}=$ glycine, pro $=$ proline, $\mathrm{ohp}=$ hydroxyproline. Low $=1$ to $5 \mathrm{ppm}$, med $=5$ to $20 \mathrm{ppm}$, high $=20$ to $50 \mathrm{ppm}$, vhigh $=50$ to $200 \mathrm{ppm}$. C. Coef. = Correlation coefficient. Protein $=$ protein does not match references. Skin $=$ matches the epidermal layer of skin. Glue $=$ matches animal glue collagen. ELISA results are reported as OD (optical density) reading.

\begin{tabular}{|c|c|c|c|c|c|c|c|c|c|}
\hline Sample and Location & ala & val & ile & leu & gly & pro & ohp & C. Coef. & $\begin{array}{c}\% \text { Protein } \\
\text { [ELISA (OD)] }\end{array}$ \\
\hline \multicolumn{10}{|l|}{ 71.AP.72 Beeswax } \\
\hline white tunic bot PR & 15 & 9 & 8 & 15 & 37 & 9 & 8 & protein & $0.9 \%$ \\
\hline tunic bot PL & 12 & 10 & 7 & 18 & 36 & 15 & 3 & protein & $0.6 \%$ \\
\hline ear PR & 13 & 7 & 5 & 14 & 53 & 8 & 0.9 & protein & $0.1 \%$ \\
\hline \multicolumn{10}{|c|}{ 74.AP.11 Beeswax with egg coating } \\
\hline $\mathrm{BG}$, top $\mathrm{PL}$ & 17 & 13 & 10 & 22 & 29 & 8 & 1 & skin, 0.99 & $1.3 \%$ \\
\hline neck, PR & 23 & 15 & 9 & 24 & 19 & 10 & 0 & egg, 0.98 & high [egg (0.8)] \\
\hline skin shoulder, PR & 21 & 12 & 10 & 19 & 30 & 8 & 0 & skin, 0.96 & $0.2 \%$ \\
\hline \multicolumn{10}{|c|}{ 79.AP.141 Beeswax on plant gum black ground } \\
\hline wood edge, C PR & 14 & 13 & 9 & 20 & 32 & 12 & 1 & skin, 0.97 & low \\
\hline C bot & 18 & 16 & 15 & 9 & 29 & 13 & 1 & protein & low \\
\hline \multicolumn{10}{|l|}{ 81.AP.42 Beeswax } \\
\hline shoulder, PL & 19 & 11 & 6 & 16 & 28 & 13 & 7 & protein & low \\
\hline shoulder, PL & 14 & 5 & 3 & 8 & 44 & 14 & 13 & glue, 0.99 & low $[\operatorname{egg}(0.5)]$ \\
\hline \multicolumn{10}{|l|}{ AEIN 680 Beeswax } \\
\hline hair, $\mathrm{C}$ top & 18 & 7 & 4 & 10 & 46 & 13 & 2 & glue, 0.96 & low \\
\hline \multicolumn{10}{|c|}{ AEIN 681 Beeswax with egg coating } \\
\hline neck, PR & 12 & 4 & 4 & 8 & 49 & 13 & 10 & glue, 0.98 & $6 \%$ \\
\hline $\mathrm{BG}, \mathrm{C}$ top & 18 & 10 & 7 & 14 & 43 & 8 & 0 & glue, 0.97 & med \\
\hline unknown & 25 & 15 & 8 & 16 & 27 & 8 & 1 & egg, 0.94 & med \\
\hline \multicolumn{10}{|l|}{ AEIN 682 Beeswax } \\
\hline flesh chest, PR & 19 & 5 & 3 & 6 & 53 & 14 & 0 & glue, 0.97 & $0.4 \%$ \\
\hline hair, TL & 17 & 10 & 6 & 14 & 40 & 8 & 5 & protein & low \\
\hline \multicolumn{10}{|l|}{ AEIN 683 Beeswax } \\
\hline yellow jewelry, C & 11 & 10 & 7 & 16 & 48 & 7 & 1 & skin, 0.93 & low \\
\hline \multicolumn{10}{|c|}{ AEIN 684 Beeswax with egg coating } \\
\hline black eyelid, PL & 22 & 10 & 7 & 16 & 36 & 9 & 1 & protein & low \\
\hline edge, top PR & 27 & 12 & 7 & 17 & 28 & 8 & 1 & protein & low \\
\hline coating nose, PL & 24 & 14 & 9 & 24 & 20 & 8 & 0 & egg, 0.96 & high \\
\hline \multicolumn{10}{|l|}{ AEIN 1425 Beeswax } \\
\hline flesh neck, textile & 18 & 9 & 6 & 13 & 34 & 17 & 3 & protein & $0.3 \%$ \\
\hline \multicolumn{10}{|l|}{ AEIN 1426 Beeswax } \\
\hline white tunic, top PL & 17 & 8 & 5 & 16 & 41 & 14 & 0 & protein & high \\
\hline \multicolumn{10}{|l|}{ AEIN 1473 Beeswax } \\
\hline $\mathrm{BG}, \mathrm{C}$ top & 21 & 10 & 0 & 13 & 39 & 11 & 6 & glue, 0.93 & $0.03 \%$ \\
\hline hair & 20 & 9 & 5 & 11 & 43 & 8 & 4 & glue, 0.93 & $0.5 \%$ \\
\hline bot PR & 21 & 8 & 4 & 9 & 47 & 9 & 3 & glue, 0.95 & $0.2 \%$ \\
\hline \multicolumn{10}{|l|}{ AS 3891 Beeswax } \\
\hline green & 17 & 9 & 6 & 16 & 36 & 13 & 3 & protein & med \\
\hline grey & 16 & 4 & 2 & 6 & 36 & 20 & 18 & glue, 0.97 & high \\
\hline \multicolumn{10}{|l|}{ AS 3892 Beeswax } \\
\hline unknown & 22 & 8 & 4 & 10 & 47 & 7 & 2 & glue, 0.92 & med \\
\hline black & 17 & 8 & 5 & 13 & 47 & 8 & 2 & protein & med \\
\hline white & 21 & 12 & 8 & 17 & 33 & 9 & 1 & skin, 0.95 & med \\
\hline \multicolumn{10}{|l|}{ TR:184-2013 Beeswax } \\
\hline flesh chest, PR & 16 & 3 & 3 & 4 & 48 & 14 & 12 & glue, 0.99 & med \\
\hline \multicolumn{10}{|l|}{ 2009.16 Beeswax } \\
\hline hair, C & 17 & 7 & 6 & 13 & 47 & 7 & 4 & glue, 0.92 & low \\
\hline \multicolumn{10}{|l|}{ CA 7124 Beeswax } \\
\hline top PR & 13 & 4 & 3 & 6 & 49 & 13 & 11 & glue, 0.99 & $0.4 \%$ \\
\hline
\end{tabular}


Table 5. Cont.

\begin{tabular}{|c|c|c|c|c|c|c|c|c|c|}
\hline Sample and Location & ala & val & ile & leu & gly & pro & ohp & C. Coef. & $\begin{array}{c}\% \text { Protein } \\
\text { [ELISA (OD)] }\end{array}$ \\
\hline \multicolumn{10}{|l|}{ 32.4 Beeswax } \\
\hline black top PL & 20 & 6 & 4 & 8 & 54 & 7 & 2 & glue, 0.95 & med \\
\hline resin & 20 & 6 & 4 & 10 & 25 & 11 & 23 & protein & vhigh \\
\hline black & 13 & 9 & 8 & 14 & 46 & 8 & 2 & protein & low \\
\hline \multicolumn{10}{|l|}{ 32.6 Beeswax } \\
\hline black & 14 & 7 & 5 & 8 & 49 & 13 & 5 & glue, 0.97 & low \\
\hline wrapping & 14 & 5 & 4 & 7 & 54 & 10 & 6 & glue, 0.97 & med \\
\hline BG, edge bot & 14 & 5 & 4 & 9 & 44 & 16 & 9 & glue, 0.98 & med \\
\hline \multicolumn{10}{|l|}{ 6-21377 Beeswax } \\
\hline grey $\quad$ BG & 19 & 9 & 6 & 15 & 36 & 11 & 5 & protein & $1 \%$ \\
\hline \multicolumn{10}{|l|}{ UC19607 Beeswax } \\
\hline white BG, C PL & 16 & 6 & 4 & 10 & 40 & 13 & 11 & glue, 0.99 & med \\
\hline \multicolumn{10}{|l|}{ UC19608 Beeswax } \\
\hline \multicolumn{10}{|l|}{ UC19612 Beeswax } \\
\hline $\begin{array}{l}\text { white BG, C PL } \\
\text { UC33971 Beeswax }\end{array}$ & \multicolumn{8}{|c|}{ UC33971 Beeswax } & low \\
\hline $\begin{array}{c}\text { BG, edge, } \\
\text { PR }\end{array}$ & 15 & 6 & 5 & 15 & 44 & 10 & 5 & glue, 0.93 & med \\
\hline \multicolumn{10}{|c|}{ 74.AP.20 Glue tempera with egg coating } \\
\hline mace, PL & 19 & 8 & 5 & 12 & 38 & 13 & 5 & glue, 0.96 & $\begin{array}{c}3 \% \\
\text { [egg }(0.3) \text { glue } \\
(0.3)]\end{array}$ \\
\hline tunic, PR & 17 & 5 & 3 & 8 & 44 & 15 & 8 & glue, 0.99 & $2 \%$ \\
\hline tunic, $\mathrm{PR}$ & 19 & 7 & 4 & 11 & 40 & 12 & 7 & glue, 0.97 & $1 \%$ \\
\hline \multicolumn{10}{|c|}{ 74.AP.21 Glue tempera with egg coating } \\
\hline tunic, PL & 20 & 8 & 5 & 10 & 39 & 12 & 7 & glue, 0.97 & $\begin{array}{c}5 \% \\
{[\text { egg }(0.4) \text { glue }} \\
(0.4)]\end{array}$ \\
\hline \multicolumn{10}{|c|}{ 74.AP.22 Glue tempera with egg coating } \\
\hline $\begin{array}{l}\text { yellow top, PL } \\
\text { 75.AP.87 Glue tempera }\end{array}$ & 18 & 6 & 4 & 9 & 42 & 13 & 9 & glue, 0.99 & $3 \%[\operatorname{egg}(0.24)]$ \\
\hline white tunic, bot PL & 15 & 4 & 2 & 6 & 44 & 16 & 14 & glue, 0.99 & med \\
\hline $\begin{array}{l}\text { BG, center } \\
\text { PR }\end{array}$ & 17 & 7 & 4 & 10 & 38 & 15 & 10 & glue, 0.99 & low [glue (0.4)] \\
\hline cheek, PL & 18 & 4 & 2 & 5 & 46 & 13 & 11 & glue, 0.99 & med \\
\hline \multicolumn{10}{|l|}{ 79.AP.129 Glue tempera } \\
\hline $\mathrm{BG}, \mathrm{C}$ top & 16 & 6 & 4 & 9 & 46 & 11 & 8 & glue, 0.98 & med \\
\hline tunic, bot PR & 15 & 6 & 4 & 10 & 49 & 10 & 6 & glue, 0.96 & med \\
\hline bot PR & 18 & 3 & 2 & 5 & 53 & 10 & 8 & glue, 0.99 & high \\
\hline \multicolumn{10}{|l|}{ 79.AP.142 Glue tempera } \\
\hline flesh hand, bot PL & 17 & 5 & 3 & 7 & 43 & 15 & 10 & glue, 0.99 & $2 \%$ \\
\hline BG, top PR & 18 & 5 & 3 & 7 & 46 & 14 & 8 & glue, 0.99 & $1 \%$ \\
\hline clavi, bot PL & 19 & 6 & 4 & 9 & 40 & 13 & 9 & glue, 0.99 & $1 \%$ \\
\hline \multicolumn{10}{|l|}{ 79.AP.129 Glue tempera } \\
\hline $\mathrm{BG}, \mathrm{C}$ top & 16 & 6 & 4 & 9 & 46 & 11 & 8 & glue, 0.98 & med \\
\hline tunic, bot $\mathrm{C}$ & 15 & 6 & 4 & 10 & 49 & 10 & 6 & glue, 0.96 & med \\
\hline clavi, bot PL & 18 & 3 & 2 & 5 & 53 & 10 & 8 & glue, 0.99 & low \\
\hline $\begin{array}{l}\text { 81.AP.29 Glue tempera } \\
\text { grey side, bot PL } \\
\text { 91.AP.6 Glue tempera }\end{array}$ & 18 & 4 & 2 & 5 & 55 & 8 & 8 & glue, 0.99 & $0.8 \%$ \\
\hline hair, top PR & 14 & 9 & 7 & 16 & 35 & 18 & 1 & protein & $\begin{array}{c}2 \% \\
{[\operatorname{egg}(0.7) \text { glue }} \\
(0.4)]\end{array}$ \\
\hline neck, bot PR & 12 & 5 & 4 & 7 & 42 & 15 & 15 & glue, 0.99 & $0.6 \%$ \\
\hline ground & 15 & 7 & 5 & 13 & 45 & 9 & 7 & glue, 0.94 & $3 \%$ \\
\hline
\end{tabular}


Table 5. Cont

\begin{tabular}{|c|c|c|c|c|c|c|c|c|c|}
\hline Sample and Location & ala & val & ile & leu & gly & pro & ohp & C. Coef. & $\begin{array}{c}\% \text { Protein } \\
\text { [ELISA (OD)] }\end{array}$ \\
\hline \multicolumn{10}{|l|}{ AS 8940 Glue tempera } \\
\hline flesh & 18 & 9 & 6 & 18 & 33 & 12 & 3 & skin, 0.94 & high \\
\hline black & 19 & 8 & 5 & 13 & 40 & 14 & 3 & glue, 0.93 & high \\
\hline \multicolumn{10}{|c|}{ AEIN 685 Gum tempera with glue ground } \\
\hline white ground & 16 & 6 & 1 & 4 & 44 & 18 & 10 & glue, 0.99 & high \\
\hline \multicolumn{10}{|l|}{ AEIN 684 Glue tempera } \\
\hline dress & 21 & 4 & 1 & 3 & 47 & 15 & 10 & glue, 0.99 & high \\
\hline \multicolumn{10}{|l|}{ VL.2015.5 Glue tempera } \\
\hline dk.grey edge, top PL & 15 & 8 & 5 & 9 & 43 & 12 & 8 & glue, 0.98 & $1 \%$ \\
\hline lt.grey edge, $C$ bot & 15 & 8 & 5 & 11 & 41 & 12 & 7 & glue, 0.97 & $0.7 \%$ \\
\hline \multicolumn{10}{|l|}{ M.71.73.62 Glue tempera } \\
\hline clavi & 16 & 5 & 3 & 7 & 46 & 12 & 11 & glue, 0.99 & med \\
\hline \multicolumn{10}{|l|}{ JLS.22226 Glue tempera } \\
\hline flesh & 18 & 7 & 4 & 7 & 46 & 10 & 7 & glue, 0.98 & med \\
\hline grey & 17 & 4 & 2 & 4 & 51 & 11 & 10 & glue, 0.99 & med \\
\hline \multicolumn{10}{|l|}{ 1935.551 Glue tempera } \\
\hline blue & 14 & 3 & 2 & 7 & 50 & 10 & 13 & glue, 0.98 & high \\
\hline red & 14 & 4 & 3 & 8 & 48 & 10 & 13 & glue, 0.97 & low \\
\hline \multicolumn{10}{|l|}{ 5-2327 Glue tempera } \\
\hline $\mathrm{BG}, \mathrm{C} P \mathrm{PR}$ & 20 & 9 & 6 & 10 & 37 & 10 & 8 & glue, 0.96 & high \\
\hline tunic & 9 & 4 & 4 & 9 & 42 & 12 & 19 & glue, 0.95 & high \\
\hline \multicolumn{10}{|l|}{ 6-21384 Glue tempera } \\
\hline red sleeve, PL & 14 & 4 & 3 & 6 & 51 & 20 & 11 & glue, 0.98 & $5 \%$ \\
\hline sleeve, PL & 12 & 3 & 3 & 6 & 47 & 11 & 16 & glue, 0.98 & high \\
\hline \multicolumn{10}{|l|}{ 6-21385 Glue tempera } \\
\hline white nimbus, PR & 18 & 9 & 7 & 12 & 34 & 12 & 8 & glue, 0.97 & $2 \%$ \\
\hline \multicolumn{10}{|l|}{ 6-21386 Glue tempera } \\
\hline blue tunic, PL & 20 & 9 & 6 & 12 & 35 & 12 & 6 & glue, 0.95 & high \\
\hline tunic, PL & 17 & 12 & 9 & 16 & 26 & 15 & 6 & protein & high \\
\hline \multicolumn{10}{|l|}{ 6-21387 Tempera } \\
\hline bot PR & 11 & 8 & 9 & 17 & 32 & 17 & 6 & protein & med \\
\hline bot PR & 12 & 8 & 9 & 15 & 37 & 16 & 4 & protein & med \\
\hline \multicolumn{10}{|l|}{ UC 14768 Glue tempera } \\
\hline white tunic, $\mathrm{C}$ & 16 & 4 & 3 & 7 & 49 & 13 & 9 & glue, 0.99 & high \\
\hline BG, PL & 16 & 4 & 2 & 6 & 47 & 14 & 11 & glue, 0.99 & high \\
\hline
\end{tabular}

\subsection{Amino acid, ELISA, and Peptide Analysis: Egg Protein}

Egg protein was identified by amino acid analysis as a final coating on two portraits (AEIN 681 and AEIN 684) that appeared as cracked islands on the surface. Also, immunological testing with enzyme-linked immunosorbent assay (ELISA) identified the presence of egg coatings on another beeswax portrait (JPGM 74.AP.11) and three glue tempera panel paintings (JPGM 74.AP.20-22). Figure 6 shows results for a mummy portrait (JPGM 74.AP.11) and details of an area showing the cracked coating on the vertical purple stripe of the tunic (clavi). The GC/MS amino acid results of the coating matched egg (0.98). A recent analysis by Kirby [41] utilizing Peptide Mass Fingerprint (PMF) on the egg coatings from mummy portraits (JPGM 74.AP.11 and JPGM 74.AP.20), further identified the coatings as whole egg from hen based on the observance of characteristic marker ions for hen egg glair and yolk. Some peptides showed a high degree of deamidation, which can be caused by time, temperature, and chemical processing [42]. Further research is planned to understand the presence of the coating in this condition. 

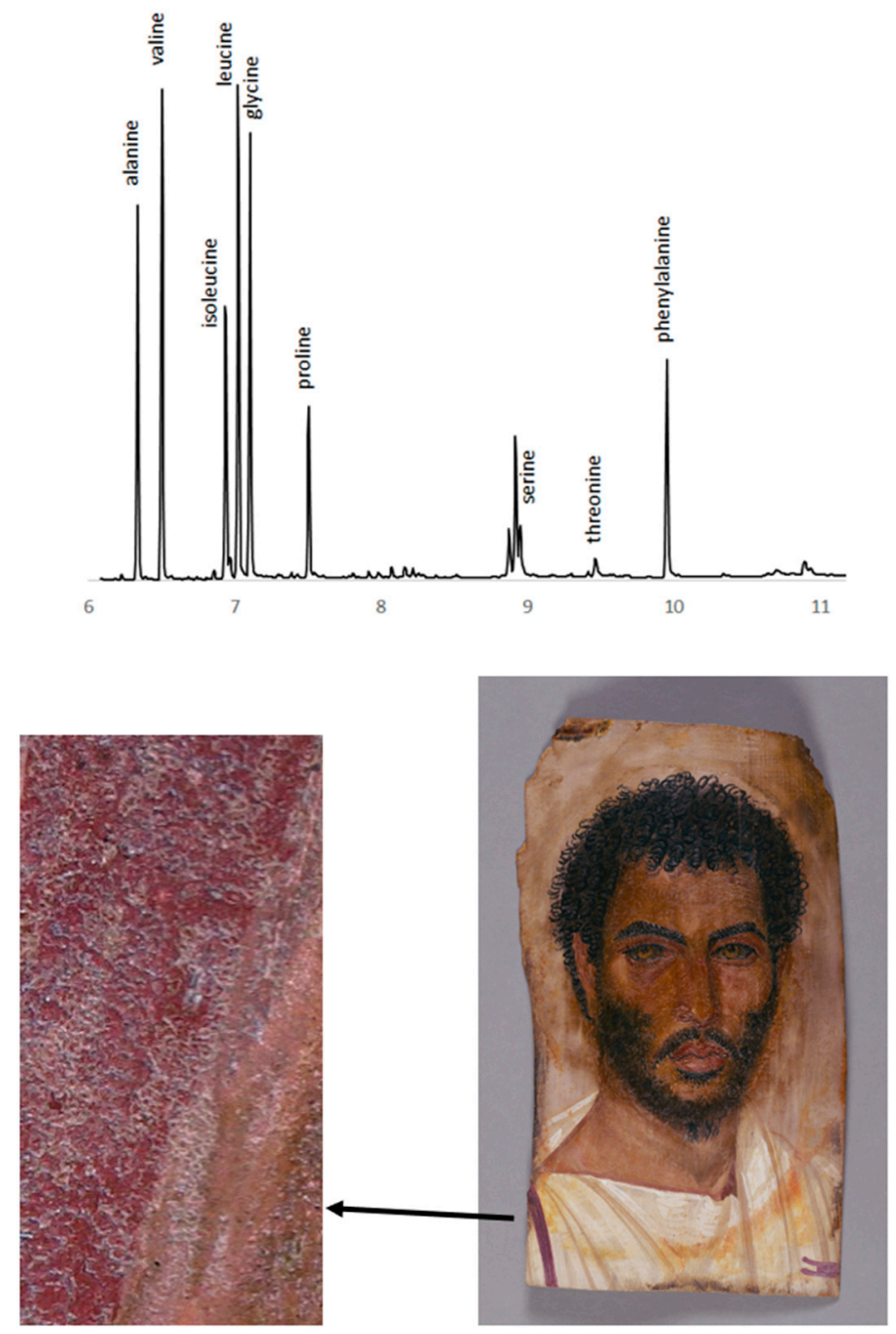

Figure 6. Beeswax portrait of a man (JPGM 74.AP.11) bottom right image. The top image is a GC/MS partial TIC chromatogram showing that amino acid analysis of the coating matched egg (0.98). The coating is white, cracked and islands are visible (image bottom left). Detail shown is at 20X light microscope. Photo by Marie Svoboda.

\subsection{Mixtures of Organic Materials}

Difficulties in interpretation arose when mixtures of organic materials were present. For example, Figure 7 shows the fatty acid analysis of a glue tempera portrait on linen (JPGM 75.AP.87). A white paint sample from the tunic showed the presence of $34 \%$ high molecular weight dicarboxylic fatty acids and $7 \%$ azelaic acid, strongly suggesting the presence of oxidized oil. Additionally, erucic acid, an unsaturated fatty acid (13-docosenoic acid) labeled $\mathrm{C}_{22-1}$ was detected, that is a biomarker for Brassicaceae (mustard seed oil). Oxidized oil was not detected in samples of black paint from the background, although it was present in yellow paint from the bird, the white tunic, and flesh-colored paint from the face. These results indicate that embalming material was not the source of oil in this case, otherwise, it would have been detected in all the samples analyzed from the black background. Figure 8 shows that the amino acid acids identified in the white tunic sample closely matched animal glue ( 0.99 correlation coefficient). 


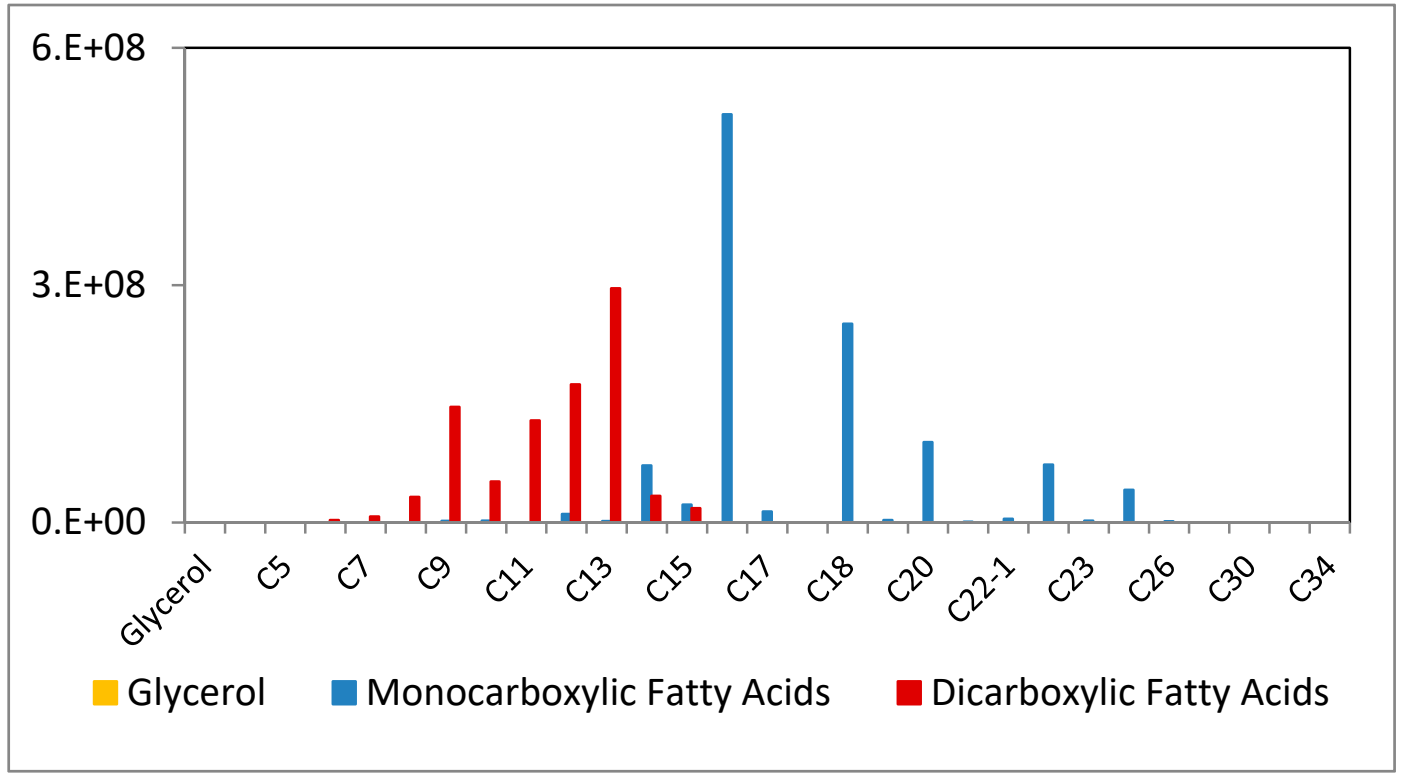

Figure 7. Peak area results from the portrait of a boy on linen (JPGM 75.AP.87).
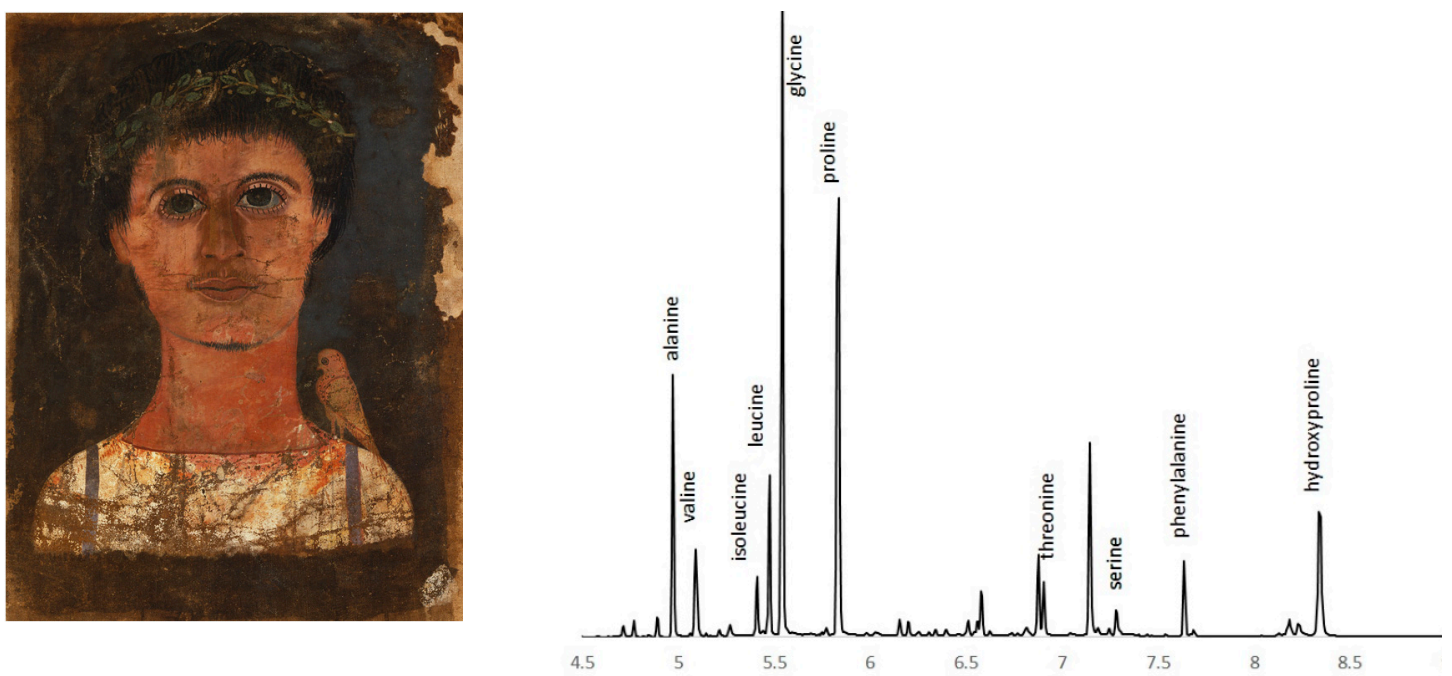

Figure 8. Portrait of a boy on linen (JPGM 75.AP.87). GC/MS partial chromatogram of amino acids from a white tunic paint sample matches animal glue (0.99).

\subsection{Monosaccharide Analysis: Plant Gums}

Plant gums were identified by monosaccharide ratios, and the results are summarized in Table 6 . If the sample weight was not measured, a semi-quantitative value of carbohydrate content was reported based on the detected value of carbohydrates in parts per million $(\mathrm{mg} / \mathrm{L})$. As the analysis required a second sample, this limited the number of paintings that were tested. Plant gum was identified in the grey background from the mummy portrait (JPGM 79.AP.142); the best match was to Acacia sp. Gum, with an additional unknown source of glucose. The Acacia sp. gum was indicated by the presence of arabinose and galactose, whereas the more commonly-known gum Arabic (Acacia Senegal), harvested from Senegal, also contains rhamnose. Therefore, Acacia sp. gum, a genus of tree native to North Africa, was identified as a possible source. The green paint from portrait panel (AEIN 685) contained gum tempera (perhaps Acacia sp.) with a white-colored glue ground. Most portraits tested contained variable amounts of glucose and/or xylose which may originate from degraded monosaccharides migrating into the paint from the wood. 
Table 6. Monosaccharide analysis results. $\%$ monos $=$ percent monosaccharides in paint sample (mg/mg). Gum content based on parts per million monosaccharides: low $=1$ to $5 \mathrm{ppm}$, med $=5$ to $20 \mathrm{ppm}$, high $=20$ to $50 \mathrm{ppm}$, vhigh $=50$ to $200 \mathrm{ppm}$. Rha $=$ rhamnose, fuc $=$ fucose, ara $=$ arabinose, $\mathrm{xyl}=$ xylose, $\operatorname{man}=$ mannose, $\mathrm{glu}=$ glucose, gal $=$ galactose .

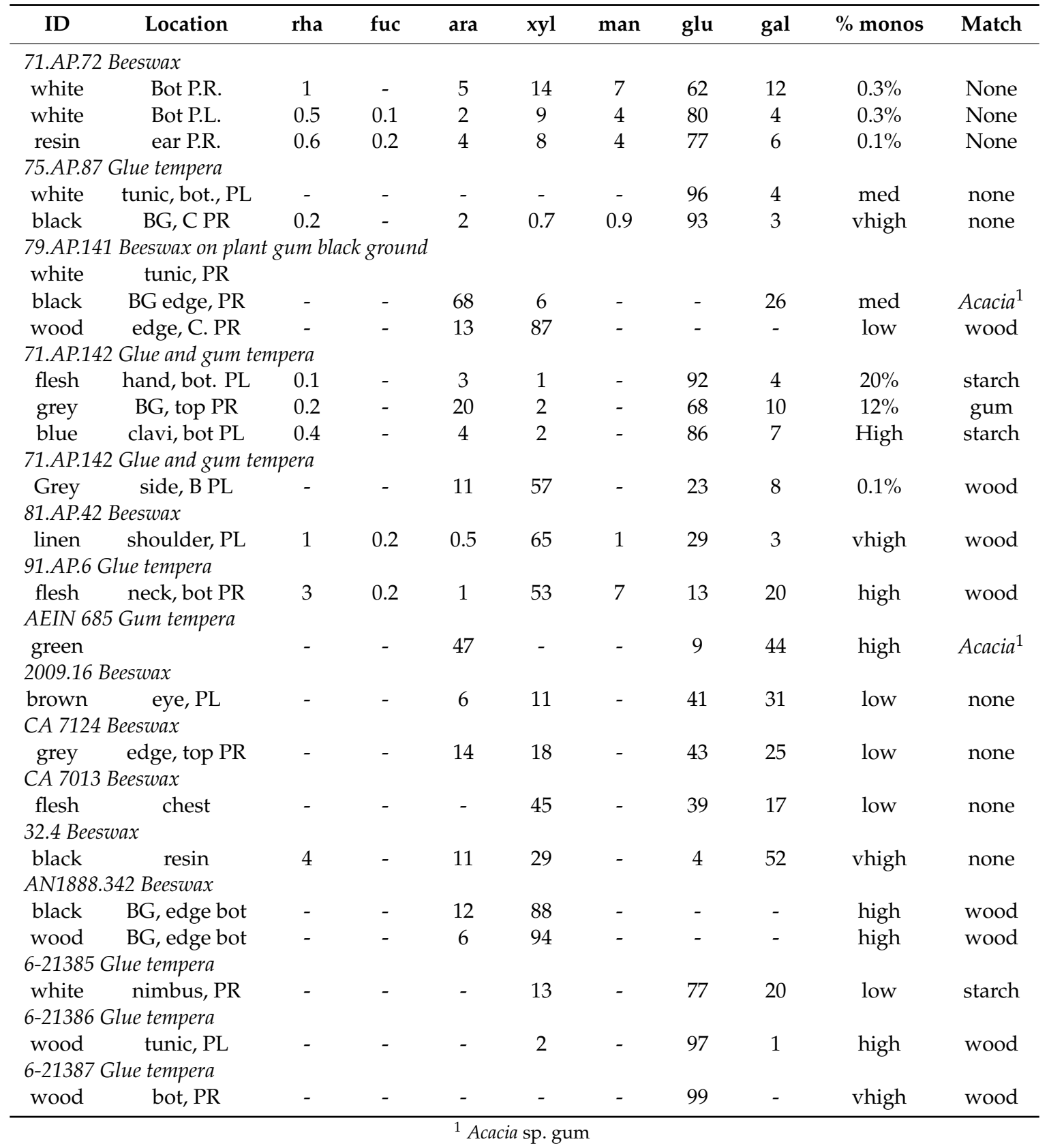

\subsection{Sampling Strategies}

Whenever possible, samples were selected to avoid areas with prior interventions. Figure 9 shows that restorations were visible in the ultraviolet-induced visible fluorescence image of a portrait (79.AP.142). In-painting is visible on the forehead, mustache, right ear lobe, around both lips, and the lower beard. Interestingly, the image also shows fluorescence characteristic of madder on the rose petal garland, wine glass, stitching on the tunic at the neckline and his face, and the rose color in the cheeks. 

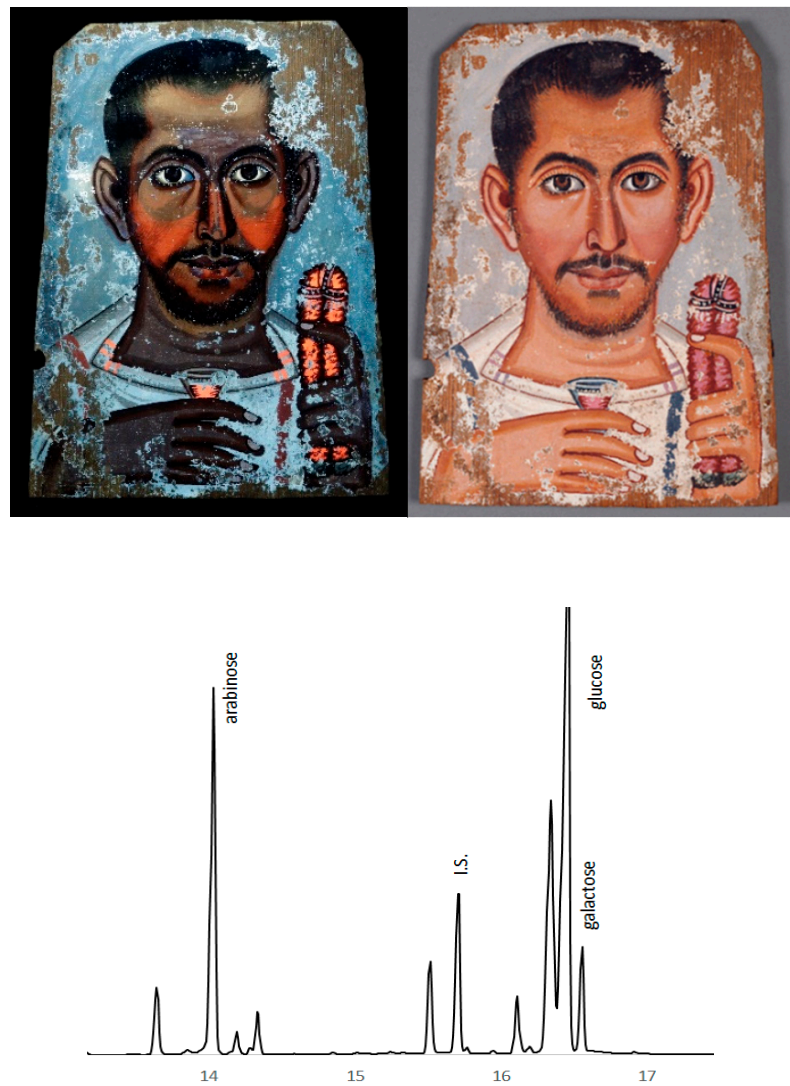

Figure 9. Top right shows visible image of portrait (JPGM 79.AP.142). The top left shows ultraviolet-induced visible fluorescence image. Light source: Wildfire Long throw series $365 \mathrm{~nm}$. Camera: Canon Rebel EOS, Peca 916 filter, 2016 by Marie Svoboda. The bottom is a partial TIC of the monosaccharides from the grey background of the portrait. I.S.=internal standard (allose).

\section{Discussion}

\subsection{Beeswax Characterization}

Thirty-three portraits contained beeswax likely from Apis melifera, the most common North African honeybee that was harvested for thousands of years in ancient Egypt for its honey and beeswax [43]. Beeswax composition of $A$. melifera is well known and contains relatively high amounts of lignoceric acid $\left(\mathrm{C}_{24}\right)$ when compared to other species such as Apis cerana [44,45]. In general, modern beeswax is composed of $14 \%$ hydrocarbons, $35 \%$ monoesters, $3 \%$ diesters, and $12 \%$ free fatty acids [46]. Beeswax contains several different types of wax esters including hydroxy monoesters and diesters with chain lengths of $\mathrm{C}_{54}$ and $\mathrm{C}_{64}$. The most abundant wax esters are composed of palmitic acid $\left(\mathrm{C}_{16}\right)$ with long-chain alcohols that vary in chain length $\left(\mathrm{C}_{40}, \mathrm{C}_{42}, \mathrm{C}_{44}, \mathrm{C}_{46}\right.$, and $\left.\mathrm{C}_{48}\right)$.

A GC/MS chromatogram of 19th century beeswax is shown in Figure 2 and the composition is remarkably similar to fresh beeswax. By comparison, samples of beeswax from the mummy portraits contain significant amounts of palmitic acid relative to other fatty acids such as lignoceric acid and wax esters. Figure 10 is a peak area percentage plot of total wax esters versus unesterified palmitic acid for various paint samples from the beeswax portraits, with data for modern beeswax and the ancient wax tablet included for reference. Modern beeswax and the ancient wax tablet group together at the top left of the graph because of relatively low content of unesterified palmitic acid (less than $10 \%$ ) and high wax ester content (greater than $80 \%$ ). 


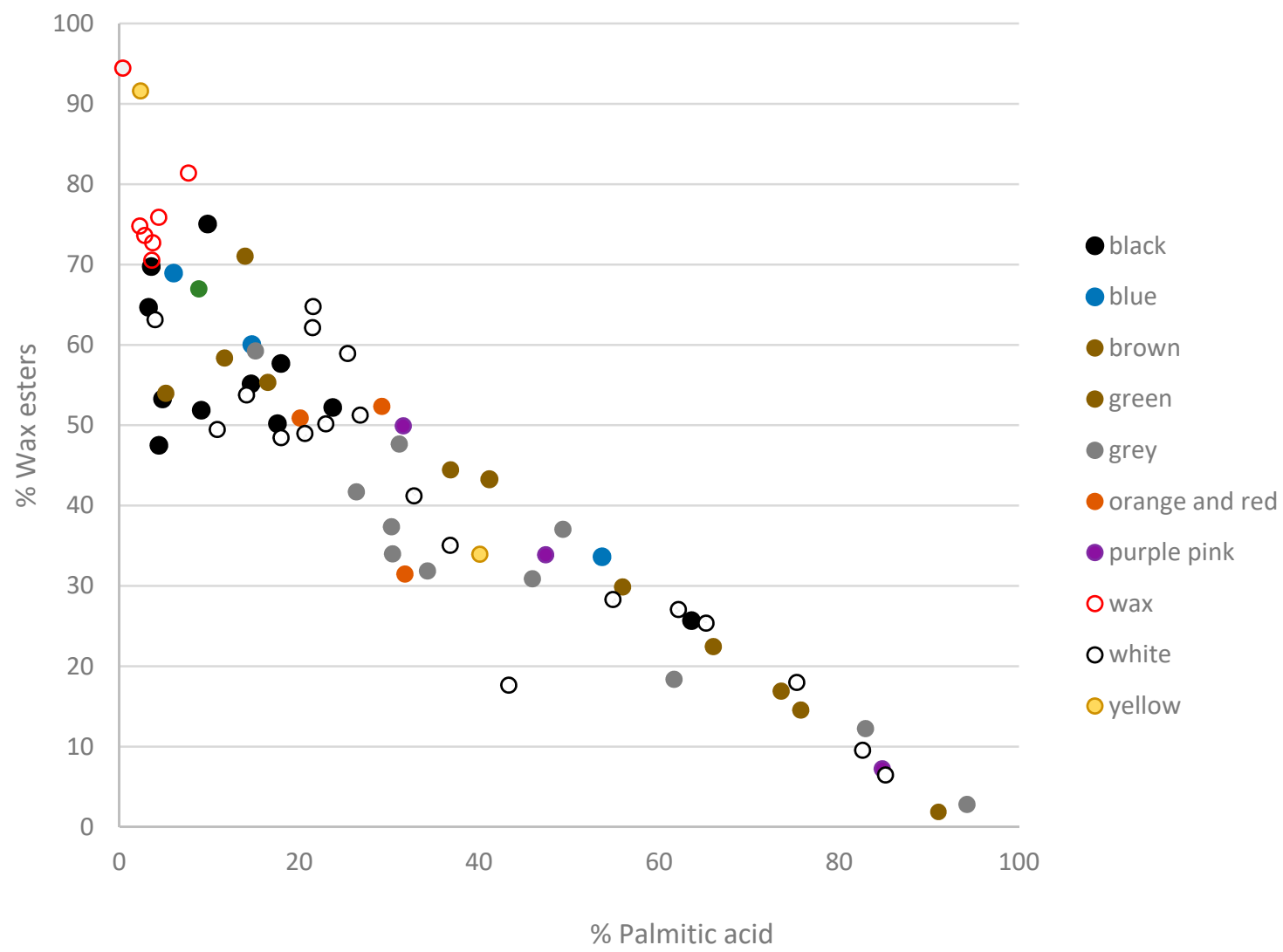

Figure 10. Peak area percentage plot of total wax esters versus palmitic acid for paints from beeswax portraits. Paint color is indicated by the legend.

The data show a negative correlation between wax ester content and unesterified palmitic acid, which is consistent with the formation of palmitic acid by hydrolysis of the wax esters. Considering that free palmitic acid evaporates readily from paints, variation in the amount of unesterified palmitic acid in the portraits is likely correlated to the content of lead palmitate soaps formed by reaction with lead-based pigments. Hydrolysis of the wax esters and formation of lead palmitate may be affected by environmental conditions during burial, or exposure to humidity prior to burial. Also, the black paints (black circles) and reference samples of beeswax without pigment (clear circles) cluster together at the top left quadrant of the graph. Perhaps this is because the black paints do not contain significant amounts of lead and are less likely to form soaps.

\subsection{Oxidized Oil}

Over half of the beeswax portraits contained evidence of oxidized oil. Figure 11 gives the area percentages of high molecular weight dicarboxylic fatty acids versus azelaic acid in a scatter plot for paint samples that exhibit evidence for oil. Dicarboxylic fatty acids, often considered as marker compounds for drying oils in paintings, were identified in some of the beeswax portraits and in one tempera portrait. Pigment type did not correlate to the presence of oil.

High molecular weight dicarboxylic acids are composed of 10 to 15 carbons while azelaic acid contains 9 carbons. Azelaic acid is formed by oxidation of unsaturated fatty acids such as oleic acid $\left(C_{18: 1}\right.$ fatty acid). In contrast, dicarboxylic acids above 9 carbons in length could come from many sources, and Evershed [47] reported they form in arid climates. High molecular weight dicarboxylic acids such as undecanedioic acid $\left(\mathrm{DC}_{11}\right)$, dodecanedioic acid $\left(\mathrm{DC}_{12}\right)$, and tridecanedioic acid $\left(\mathrm{DC}_{13}\right)$ have been reported as markers for Brassicaceae oil or mustard seed oil [48]. Specifically, the identification of the fatty acid biomarker erucic acid $\left(C_{22: 1}\right)$ further supports the presence of a Brassicaceae or mustard family seed oil. 


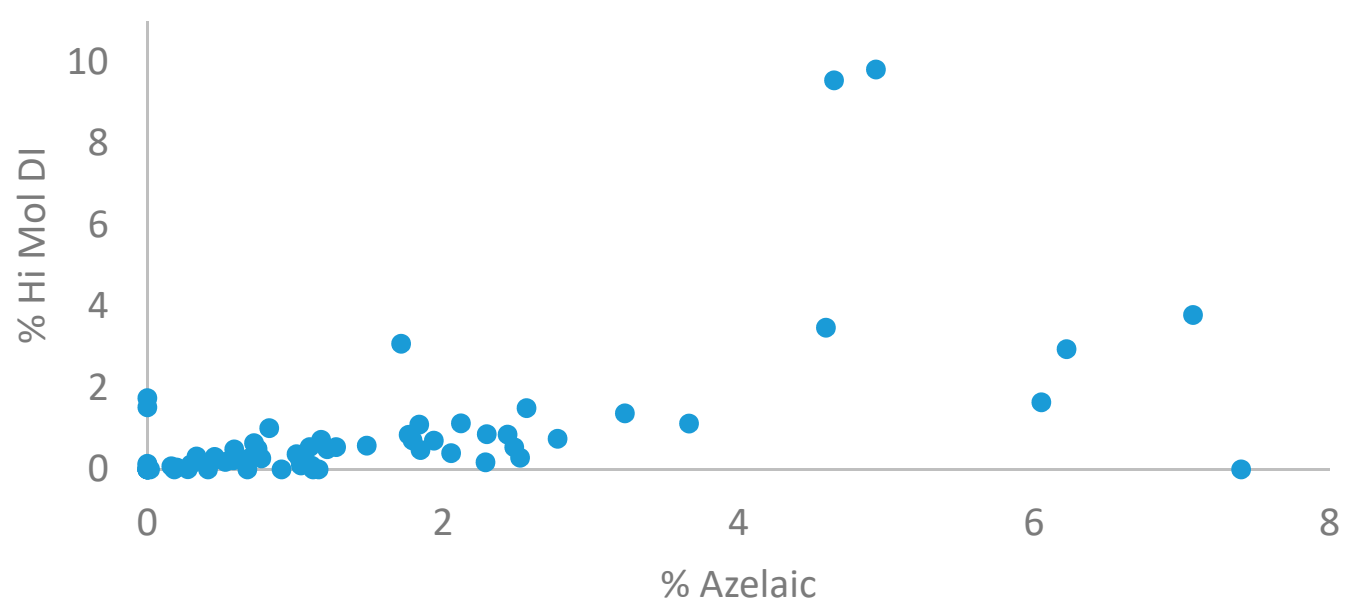

Figure 11. Scatter plot of dicarboxylic acids. Hi Mol DI=\% dicarboxylic fatty acids with 10 to 15 carbons on $\mathrm{y}$-axis and \% azelaic acid with 9 carbons on $\mathrm{x}$-axis.

The J. Paul Getty glue tempera portrait (JPGM 75.AP.87) contained 35\% high molecular weight dicarboxylic acids. Oxidized oil was identified in the figure but not the black background, thus mummification unguents are not likely their source. Two portraits from the Menil collection, considered to be modern forgeries, were in fact oil paintings. They contained $45 \%$ azelaic acid which is typical of drying oils, and these portraits are not included in the data plotted in Figure 11. Erucic acid was identified in a glue portrait on linen (JPGM 75.AP.87), a beeswax portrait from the Petrie Museum (UC 19608), a beeswax portrait from the Walters Museum (32.4), and a beeswax portrait with egg coating (JPGM 74.AP.11). Additionally, the mummy portrait (JPGM 74.AP.11) contained oil in the flesh color from the face, the white background, and the tunic. The presence of erucic acid in these portraits is consistent with Brassicaceae or mustard family seed oil. Two beeswax portraits (73.AP.94 and AEIN 680 ), that were described as flat and lean, did not contain oil. Future research is necessary to correlate the appearance of beeswax paint with the presence or absence of oil.

\subsection{Oil and Beeswax: Evidence for Additive or Restoration Treatment?}

There are several possible explanations for the presence of oxidized oils: either it was added intentionally by the artists, or it is contamination from restoration treatments or embalming oils. The Greeks and Romans, acquainted with oil painting, mixed oil with wax to render the medium more flexible and easily applicable. The "ganosis" technique is described as wax melted and diluted with a little oil [49]. However, Petrie described his displeasure when discovering paintings "injured" due to oil from mummification soaking through the wood panel and darkening the paint. Some portraits became completely obscured due to the dark stains caused by the oil. Decay occurred due to damp conditions, presumably by biodeterioration, causing their destruction.

In one glue tempera portrait (JPGM 75.AP.87), the source of the oil did not appear to be from mummification materials because oil was not detected in several different areas of black paint from the background. Oil was present in the yellow paint from the bird, the white tunic, and flesh-colored paint from the face. These results indicate that the embalming oil was not the source of oil in this paint, otherwise, it would have been detected in the black background. Testing of the top and bottom of select paint fragments from different objects showed that, in those specific cases, the oxidized oil did not appear to be a coating localized on the surface because the amount of dicarboxylic acid did not decrease with depth (Table 4). Embalming material, not available for testing in this study, would be an important reference material to test for oils, animal fats, and other lipids. The sources of oil in the portraits require further investigation. 


\subsection{The Indicators for Modified Beeswax}

The descriptions of beeswax portraits have been cited as evidence that the wax was modified. For example, a mummy portrait from the Ny Carlsberg Glyptotek (AEIN 1425) was described as "a rich oil-paint texture suggesting wax used cold" [4]. In this present study, oxidized oil was identified in this beeswax portrait. In this same publication (page 167), a mummy portrait from the Cleveland Museum of Art (1971.136) was described as painted on by brush and "having the effect of an oil painting." Unfortunately, binding media results from this portrait showed that it was heavily restored and treated with paraffin wax, so oil could not be reliably identified. In this same publication (page 180), a beeswax mummy portrait from the J. Paul Getty Museum (JPGM 79.AP.141) was described as the "surface of the painting is covered with fine vertical cracks, suggesting the use of Punic wax mixed with oil." In our study, this painting was found to contain a gum tempera ground layer and beeswax paint ( $21 \%$ palmitic acid, 33\% wax esters) with no evidence for oxidized oil. The cracking beeswax paint is likely due to the incompatibility of the paint layers-the wax was applied over the gum tempera ground layer-and not due to the presence of oil.

An encaustic portrait from the Petrie Museum (UC 19612) was re-examined because it was previously identified as "modified" wax by White [12] due to the relatively low amounts of beeswax esters and the presence of brush marks. Results from this current study show that a sample from the background contained $24 \%$ palmitic acid, $39 \%$ wax esters, $2 \%$ dicarboxylic acids, and low amounts of animal glue. In contrast, white paint from mummy portrait (JPGM 71.AP.72), which had the appearance of being applied hot, contained fewer wax esters (10\%), significantly more palmitic acid (50\%), $5 \%$ dicarboxylic acids, and $0.9 \%$ unknown protein. These results support the assumption that "modified" beeswax (if present) is very difficult to identify by chemical methodologies.

\subsection{Animal Glue Tempera and Protein}

Amino acids are ubiquitous in beeswax portraits; most of the portraits examined had variable amounts of protein that matched animal glue. For a few samples, the amino acid compositions matched skin epidermis, or did not match known reference materials. Although glue may have been added intentionally to the wax, it may also have been applied as a preparation layer to seal the wood before painting or as a consolidant in restorations. Significantly, the amino acid data indicated that animal glue was the preferred tempera medium, as the vast majority of the tempera paintings were painted with glue, whereas egg paint medium has yet to be confirmed.

The identification of egg in coatings from five mummy portraits and three panel paintings was accomplished by amino acid and ELISA methods. Five of the paintings are presumed to be from the er-Rubayat region (Table 1), so it is possible that the egg coating could be a restoration treatment by Graf or others. However, the egg coatings appear to be very old and degraded, and many of the remaining portraits in this study were not examined with the attentiveness to identify coatings. The identification of additional portraits with egg coatings and the characterization of the species of bird egg by using proteomics would be an interesting subject of future research.

\section{Conclusions}

The binding media survey presented here summarized the results of 61 Romano-Egyptian paintings. It utilized GC/MS protocols capable of identifying the presence of beeswax, soaps, oils, and protein in single micro-samples of paint. The protocols enabled differentiation of modern and ancient beeswax, as well as paraffin wax. Beeswax mummy portraits showed a prevalence of lead soaps, likely due to the hydrolysis of wax esters over time. Oxidized oil was identified for the first time in more than half of the beeswax portraits and in one tempera portrait. The fatty acid analysis revealed the presence of oxidized oil due to the presence of high molecular weight dicarboxylic fatty acids, as well erucic acid, a biomarker fatty acid from the mustard family (Brassicaceae). Amino acid analysis was used to identify egg coatings, and the prevalence of animal glue in tempera paints. The results of the 
survey were enhanced by using consistent protocols for the study of ancient binding media, advanced technologies and collaborations fostered through the APPEAR project.

Author Contributions: Methodology, J.M.; software and editing, M.S. (Michael Schilling); formal analysis, J.M.; original draft preparation, J.M.; writing—review and editing, M.S. (Marie Svoboda) and M.S. (Michael Schilling).

Acknowledgments: Lin Spaabaek, conservator, for first discovering the visual indications of egg coatings on beeswax portraits from NY Carlsberg Glyptotek. Corina Rogge, Museum of Fine Arts Houston for supplying samples and materials. Giacomo Chiari and Tom Learner, Head of Science, GCI, for encouragement and support.

Conflicts of Interest: The authors declare no conflict of interest.

\section{References}

1. Borg, B.E.; Most, G.W. The Face of the Elite. Arion 2000, 8, 63-96.

2. Walker, S. Ancient Faces: Mummy Portraits from Roman; Egypt; Taylor \& Francis: Didcot, UK, 2000.

3. Freccero, A. Fayum Portraits: Documentation and Scientific Analyses of Mummy Portraits Belonging to Nationalmuseum in Stockholm; Acta Universitatis Gothoburgensis: Gothenburg, Sweden, 2000.

4. Doxiadis, E. The Mysterious Fayum Portraits: Faces from Ancient Egypt; Harry, N., Ed.; Abrams: New York, NY, USA, 1995.

5. Picton, J.; Quirke, S.; Roberts, P.C. LIVING Images: Egyptian Funerary Portraits in the Petrie Museum; Routledge: Abingdon, UK, 2018.

6. Petrie, W.M.F. Hawara, Biahmu, and Arsinoe; Field \& Tuer: London, UK, 1889.

7. Borg, B. The Dead as a Guest at Table? Continuity and Change in the Egyptian Cult of the Dead. 1997. Available online: https://core.ac.uk/download/pdf/35120463.pdf (accessed on 1 March 2019).

8. Petrie, W.M.F. Seventy Years in Archaeology; Cambridge University Press: Cambridge, UK, 2013.

9. Thompson, D.L. Mummy Portraits in the J. Paul Getty Museum; Getty Publications: Los Angeles, CA, USA, 1982.

10. Bagh, T. Archival photo of Petrie's exhibition at University College London in 1911 showing the mummies and portraits from Hawara. In Finds from W.M.F Petrie's Excavations in Egypt on the Nu Carlsberg Glyptotek; ISD LLC: Bristol, CT, USA, 2011; Volume 9.

11. Cotte, M.; Checroun, E.; Susini, J.; Dumas, P.; Tchoreloff, P.; Besnard, M.; Walter, P. Kinetics of oil saponification by lead salts in ancient preparations of pharmaceutical lead plasters and painting lead mediums. Talanta 2006, 70, 1136-1142. [CrossRef]

12. White, R. The application of gas-chromatography to the identification of waxes. Stud. Conserv. 1978, 23, 57-68. [CrossRef]

13. Kühn, H. Detection and Identification of Waxes, Including Punic Wax, by Infra-red Spectrography. Stud. Conserv. 1960, 5, 71-81. [CrossRef]

14. Regert, M.; Colinart, S.; Degrand, L.; Decavallas, O. Chemical Alteration and Use of Beeswax Through Time: Accelerated Ageing Tests and Analysis of Archaeological Samples from Various Environmental Contexts. Archaeometry 2003, 43, 549-569. [CrossRef]

15. Stacey, R.J. The composition of some Roman medicines: Evidence for Pliny's Punic wax? Anal. Bioanal. Chem. 2011, 401, 1749. [CrossRef]

16. Stacey, R.J.; Dyer, J.; Mussell, C.; Lluveras-Tenorio, A.; Colombini, M.P.; Duce, C.; La Nasa, J.; Cantisani, E.; Prati, S.; Sciutto, G.; et al. Ancient encaustic: An experimental exploration of technology, ageing behaviour and approaches to analytical investigation. Microchem. J. 2018, 138, 472-487. [CrossRef]

17. Leone, R.; Breuil, C. Filamentous fungi can degrade aspen steryl esters and waxes. Int. Biodeterior. Biodegrad. 1998, 41, 133-137. [CrossRef]

18. Hunter, G.W. Laboratory preparation of cold cream to show saponification and emulsification. J. Chem. Educ. 1944, 21, 175. [CrossRef]

19. Agoston, G.A. Acrylics, oils and encaustic: Experiences and opinions of an artist-chemical engineer. Leonardo 1971, 4, 211-219. [CrossRef]

20. Vereshchagin, A.G. Occurrence of Lipophilic Micellae Formed by Fatty Alcohols and Fatty-Acid Sodium Salts in Jojoba-Wax Aqueous Hydrolyzate. Available online: http://www.dr-baumann.ca/science/Chemical\% 20composition\%20of\%20Jojba\%20Oil.pdf (accessed on 1 March 2019). 
21. Salvant, J.; Williams, J.; Ganio, M.; Casadio, F.; Daher, C.; Sutherland, K.; Monico, L.; Vanmeert, F.; De Meyer, S.; Janssens, K.; et al. A Roman Egyptian Painting Workshop: Technical Investigation of the Portraits from Tebtunis, Egypt. Archaeometry 2017, 60, 815-833. [CrossRef]

22. Henderson, J.; Morkot, R.; Peltenburg, E.; Quirke, S.; Serpico, M.; Tait, J.; White, R. Ancient Egyptian Materials and Technology; Cambridge University Press: Cambridge, UK, 2000.

23. Sack, S.P.; Tahk, F.C.; Peters, T. A technical examination of an ancient Egyptian painting on canvas. Stud. Conserv. 1981, 26, 15-23. [CrossRef]

24. Mathews, T.F.; Muller, N.E. The Dawn of Christian Art in Panel Paintings and Icons; J. Paul Getty Museum: Los Angeles, CA, USA, 2017.

25. Mazurek, J.; Svoboda, M.; Maish, J.; Kawahara, K.; Fukakusa, S.; Nakazawa, T.; Taniguchi, Y. Characterization of Binding Media in Egyptian Romano Portraits Using Enzyme-Linked Immunosorbant Assay and Mass Spectrometry. e-Preserv Sci. 2014, 11, 76-83.

26. Lluveras-Tenorio, A.; Mazurek, J.; Restivo, A.; Colombini, M.P.; Bonaduce, I. The Development of a New Analytical Model for the Identification of Saccharide Binders in Paint Samples. PLoS ONE 2012, 7, e49383. [CrossRef] [PubMed]

27. Granzotto, C.; Arslanoglu, J. Revealing the binding medium of a Roman Egyptian painted mummy shroud. J. Cult. Herit. 2017, 27, 170-174. [CrossRef]

28. Van Kuijk, F.; Thomas, D.; Konopelski, J.; Dratz, E. Transesterification of phospholipids or triglycerides to fatty acid benzyl esters with simultaneous methylation of free fatty acids for gas-liquid chromatographic analysis. J. Lipid Res. 1986, 27, 452-456.

29. Drechsel, D.; Dettmer, K.; Engewald, W. Studies of thermally assisted hydrolysis and methylation-GC-MS of fatty acids and triglycerides using different reagents and injection systems. Chromatographia 2003, 57, 283-289. [CrossRef]

30. Sutherland, K. Derivatisation using m-(trifluoromethyl) phenyltrimethylammonium hydroxide of organic materials in artworks for analysis by gas chromatography-mass spectrometry: Unusual reaction products with alcohols. J. Chromatogr. A 2007, 1149, 30-37. [CrossRef]

31. Schilling, M.R.; Khanjian, H.P.; Souza, L.A. Gas chromatographic analysis of amino acids as ethyl chloroformate derivatives. Part 1, Composition of proteins associated with art objects and monuments. J. Am. Inst. Conserv. 1996, 35, 45-59. [CrossRef]

32. Schilling, M.R.; Khanjian, H.P. Gas chromatographic analysis of amino acids as ethyl chloroformate derivatives. Part 2, Effects of pigments and accelerated aging on the identification of proteinaceous binding media. J. Am. Inst. Conserv. 1996, 35, 123-144. [CrossRef]

33. Lluveras-Tenorio, A.; Mazurek, J.; Restivo, A.; Colombini, M.P.; Bonaduce, I. Analysis of plant gums and saccharide materials in paint samples: Comparison of GC-MS analytical procedures and databases. Chem. Cent. J. 2012, 6, 1-16. [CrossRef] [PubMed]

34. Mazurek, J.; Heginbotham, A.; Schilling, M.; Chiari, G. Antibody assay to characterize binding media in paint. ICOM Comm. Conserv. 2008, 2, 678-685.

35. Schilling, M.R.; Heginbotham, A.; van Keulen, H.; Szelewski, M. Beyond the basics: A systematic approach for comprehensive analysis of organic materials in Asian lacquers. Stud. Conserv. 2016, 61, 3-27. [CrossRef]

36. Cartwright, C.R.; Bierbrier, M. Egyptian mummy portraits: Examining the woodworkers' craft. In Portraits and Masks. Burial Customs in Roman Egypt; Taylor \& Francis: Didcot, UK, 1997; pp. 106-111.

37. Cartwright, C.; Spaabaek, L.R.; Svoboda, M. Portrait mummies from Roman Egypt: Ongoing collaborative research on wood identification. Br. Mus. Tech. Res. Bull. 2011, 5, 49-58.

38. Sutherland, K.S.R.C.; Pozzi, F. Forthcoming publication: Challenges in the Characterization and Categorization of Binding Media in Mummy Portraits" in Romano-Egyptian Funerary Paintings: Emerging Research from the APPEAR Project. In Proceedings of the Getty publication of APPEAR conference, Los Angeles, CA, USA; 2018.

39. Ramer, B. The Technology, Examination and Conservation of the Fayum Portraits in the Petrie Museum. Stud. Conserv. 1979, 24, 1-13. [CrossRef]

40. Mills, J.S.; White, R. The gas-chromatographic examination of paint media. Part II. Some examples of medium identification in paintings by fatty acid analysis. Stud. Conserv. 1972, 17, 721-728. [CrossRef]

41. Kirby, D. Peptide Mass Fingerprint (PMF) of Egg on JPGM Portraits. 2019; Unpublished data. 
42. Kirby, D.; Khandekar, N.; Arslanoglu, J.; Sutherland, K. Protein identification in artworks by peptide mass fingerprinting. In Proceedings of the Preprints of ICOMCC, 16th Triennial Conference, Lisbon, Portugal, 19-23 September 2011.

43. Franck, P.; Garnery, L.; Loiseau, A.; Oldroyd, B.P.; Hepburn, H.R.; Solignac, M.; Cornuet, J.M. Genetic diversity of the honeybee in Africa: Microsatellite and mitochondrial data. Heredity 2001, 86, 420-430. [CrossRef] [PubMed]

44. Aichholz, R.; Lorbeer, E. Investigation of combwax of honeybees with high-temperature gas chromatography and high-temperature gas chromatography-chemical ionization mass spectrometry: I. High-temperature gas chromatography. J. Chromatogr. A 1999, 855, 601-615. [CrossRef]

45. Aichholz, R.; Lorbeer, E. Investigation of combwax of honeybees with high-temperature gas chromatography and high-temperature gas chromatography-chemical ionization mass spectrometry: II: High-temperature gas chromatography-chemical ionization mass spectrometry. J. Chromatogr. A 2000, 883, 75-88. [CrossRef]

46. Jiménez, J.; Bernal, J.; Aumente, S.; del Nozal, M.J.; Martín, M.T.; Bernal, J., Jr. Quality assurance of commercial beeswax: Part, I. Gas chromatography-electron impact ionization mass spectrometry of hydrocarbons and monoesters. J. Chromatogr. A 2004, 1024, 147-154. [CrossRef]

47. Evershed, R.P.; Heron, C.; Goad, J. Analysis of organic residues of archaeological origin by high-temperature gas chromatography and gas chromatography-mass spectrometry. Analyst 1990, 115, 1339-1342. [CrossRef]

48. Colombini, M.P.; Modugno, F.; Ribechini, E. Organic mass spectrometry in archaeology: Evidence for Brassicaceae seed oil in Egyptian ceramic lamps. J. Mass Spectrom. 2005, 40, 890-898. [CrossRef] [PubMed]

49. Freccero, A. Encausto and Ganosis: Beeswax as Paint and Coating during the Roman Era and its Applicability in Modern Art, Craft and Conservation; Acta Universitatis Gothoburgensis: Gothenburg, Sweden, 2002.

(C) 2019 by the authors. Licensee MDPI, Basel, Switzerland. This article is an open access article distributed under the terms and conditions of the Creative Commons Attribution (CC BY) license (http://creativecommons.org/licenses/by/4.0/). 